\title{
Anticancer Activities of Mononuclear Ruthenium(II) Coordination Complexes
}

\author{
William M. Motswainyana ${ }^{1,2}$ and Peter A. Ajibade ${ }^{1}$ \\ ${ }^{1}$ Department of Chemistry, Faculty of Science and Agriculture, University of Fort Hare, Private Bag X1314, Alice 5700, South Africa \\ ${ }^{2}$ Botswana Institute for Technology Research and Innovation, Private Bag 0082, Gaborone, Botswana \\ Correspondence should be addressed to William M. Motswainyana; mtswil004@gmail.com
}

Received 10 October 2014; Revised 18 December 2014; Accepted 25 January 2015

Academic Editor: M. Paula Robalo

Copyright (c) 2015 W. M. Motswainyana and P. A. Ajibade. This is an open access article distributed under the Creative Commons Attribution License, which permits unrestricted use, distribution, and reproduction in any medium, provided the original work is properly cited.

\begin{abstract}
Ruthenium compounds are highly regarded as potential drug candidates. The compounds offer the potential of reduced toxicity and can be tolerated in vivo. The various oxidation states, different mechanism of action, and the ligand substitution kinetics of ruthenium compounds give them advantages over platinum-based complexes, thereby making them suitable for use in biological applications. Several studies have focused attention on the interaction between active ruthenium complexes and their possible biological targets. In this paper, we review several ruthenium compounds which reportedly possess promising cytotoxic profiles: from the discovery of highly active compounds imidazolium [trans-tetrachloro(dmso)(imidazole)ruthenate(III)] (NAMI-A), indazolium [trans-tetrachlorobis(1H-indazole)ruthenate(III)](KP1019), and sodium trans-[tetrachloridobis(1Hindazole)ruthenate(III)] (NKP-1339) to the recent work based on both inorganic and organometallic ruthenium(II) compounds. Half-sandwich organometallic ruthenium complexes offer the opportunity of derivatization at the arene moiety, while the three remaining coordination sites on the metal centre can be functionalised with various coordination groups of various monoligands. It is clear from the review that these mononuclear ruthenium(II) compounds represent a strongly emerging field of research that will soon culminate into several ruthenium based antitumor agents.
\end{abstract}

\section{Introduction}

The compound cis-diamminedichloroplatinum(II) (cisplatin) has been an established antineoplastic agent in the treatment of various cancer cells since its accidental discovery by Rosenberg in the 1960s $[1,2]$. Despite its success in the treatment of tumours, the clinical effectiveness of cisplatin has been greatly limited by drug resistance and significant side effects $[3,4]$. These drug dynamics have in some cases prompted patients to refuse further treatment. The documented cisplatin limitations have triggered the development and screening of a large number of platinumbased complexes as potential antitumor agents, with a view to develop less toxic, but equally effective cisplatin analogues [3-5]. To date, two more platinum compounds are currently in clinical trial, but initial signs show that these complexes fall short in addressing many of the drawbacks associated with cisplatin [6]. Consequently, these limitations have provided an incentive for further research into other transition metal complexes in an attempt to develop novel drugs that would overcome the disadvantages associated with cisplatin therapy.

Ruthenium compounds are well known for their high relevance as drug candidates, though they have very little in common with the already existing platinum-based drugs. Antitumor potential of these compounds was established over two decades ago, but the interest to explore their cytotoxic profile was very low, possibly because they do not mimic cisplatin in their mode of action [7]. The compounds also offer the potential of reduced toxicity and can be better tolerated in vivo. This phenomenon is attributed to the ability of ruthenium to mimic the binding of iron to serum transferrin, which solubilises and transports iron in plasma, thereby exploiting the body's mechanism of nontoxic delivery of iron [8-10]. Furthermore, the various oxidation states, different mechanism of action, and kinetics of ruthenium compounds 
appear to give them several advantages over platinumbased complexes. For instance, ruthenium is known to be stable in oxidation states II, III, and IV at physiological conditions. In addition, ruthenium(III) complexes have an octahedral coordination sphere in contrast to square-planar platinum(II) complexes [11, 12]. The ligand substitution kinetics of ruthenium(II) and ruthenium(III) are also similar to platinum(II) compounds but tunable due to the strong influence of the coordinated ligands. This makes ruthenium compounds suitable for use in biological applications due to their slow ligand exchange rates, which are close to those of cellular processes [13]. It is well known that ligand exchange is an important determinant of biological activity, as very few metal drugs reach their biological targets without being chemically modified. Under physiological conditions, metal interaction with nucleic acids, proteins, sulfur, or oxygen containing compounds and water could occur in the cells, and such interactions are important for inducing therapeutic effect of a drug [13].

In recent years, many research groups have explored ruthenium compounds for their ability to inhibit tumour growth. The major focus has been on the interaction between active ruthenium complexes and their possible biological targets such DNA, RNA, transferrin, albumin, and cytochrome $c$ [14-17]. It is generally accepted that cytotoxicity of ruthenium(III) and ruthenium(II) complexes is related to their ability to bind DNA [17], although some exceptions have been reported [18]. Studies have also revealed that some ruthenium compounds could inhibit DNA replication, produce mutagenic effects, induce SOS repair, bind to DNA, and reduce RNA synthesis, thereby suggesting a DNA interaction [7]. A major research breakthrough in antitumor potency of ruthenium compounds is reflected in the discovery of three most promising ruthenium(III) complexes, imidazolium [trans-tetrachloro(dmso) (imidazole)ruthenate(III)] (NAMI-A) (1) [19-21], indazolium [trans-tetrachlorobis(1H-indazole)ruthenate(III)](KP1019)

(2a) $[22,23]$, and sodium trans-[tetrachloridobis(1H-indazole)ruthenate(III)] (NKP-1339) (2b) [24] (Figure 1). NKP-1339 is a water-soluble sodium salt of KP1019. These complexes adopt octahedral coordination geometry with respect to the ruthenium(III) metal centre, but they exhibit different biological activities despite their structural and chemical similarities. The complexes have since entered clinical trials. NKP-1339 was evaluated in a clinical phase I trial for its safety, tolerability, pharmacokinetics, and pharmacodynamics [25]. In the case of KP1019, an openlabel flat-dose escalation trial was performed in patients with advanced solid tumours without further therapeutic options $[24,25]$.

NAMI-A interferes with the interactions of tumour cells with the extracellular matrix, including an increase of actindependent cell adhesion and reduction of cell invasiveness and migration $[26,27]$. This mechanism of action by NAMIA clearly shows that its effects are directed against the process of metastasis, with little mentioned on its inhibitory potential against established tumours [26, 27], possibly due to its low capacity of binding to DNA [28]. However, it remained to be seen if the compound would successfully make it due to its negligible cytotoxicity. Previous clinical results showed that effective compounds for treating metastasis should also have capacity to exert their effect on primary tumours [7].

The redox activities of KP1019 and NPK-1339 conform to the proposed mode of action of ruthenium compounds, which involves disturbance of the cellular redox balance, followed in succession by induction of G2/M cell cycle arrest, blockage of DNA synthesis, and induction of apoptosis via the mitochondrial pathway [25]. Furthermore, their high tumour targeting potential is probably based on delivery to tumour sites by serum proteins albumin and transferrin, as well as on the activation of the compounds in the reductive tumour milieu [25]. KP1019 and NKP-1339 are administered intravenously, and their interaction with serum proteins has significant relevance. Several research findings have demonstrated a strong affinity of KP1019 and NKP-1339 to proteins in the bloodstream, in particular to albumin and transferrin [29]. A detailed investigation of the binding of the ruthenium(III) drugs to transferrin, in particular KP1019, in vitro was proven by $\mathrm{X}$-ray crystal structure analysis. X-ray crystallography experiments revealed that, after binding to histidine-253, the two indazole ligands still remain bound to the ruthenium centre [30]. It was also shown that the reaction of transferrin with KP1019 or NKP-1339 is very fast and gets completed within several minutes [31]. It is therefore evident from the literature reports that ruthenium(III) compounds have yielded significant success in recent days, and several reports based on their cytotoxicity continue to emerge. In this review, we focus particular attention on ruthenium(II) compounds which have been reported to possess promising cytotoxic profiles.

\section{Ruthenium(II) Compounds}

2.1. Organometallic Ruthenium(II) Compounds. According to the literature reports, ruthenium(III) complexes are activated by reduction to ruthenium(II), and these reports have focused current research on anticancer potential of "halfsandwich" ruthenium(II) arene compounds of the type $\left[\left(\eta^{6}\right.\right.$ arene) $\mathrm{Ru}(\mathrm{YZ})(\mathrm{X})$ ] (3) [32]. The compounds are also referred to as "piano-stool," where $\mathrm{YZ}$ is a bidentate chelating ligand and $\mathrm{X}$ is a leaving group (Figure 2) [32, 33]. These halfsandwich complexes offer the opportunity of derivatization at the arene moiety, while the three remaining coordination sites on the metal centre (X, Y, and $\mathrm{Z}$ ) can be functionalised with various coordination groups of various monoligands or bidentate ligands [32-35]. These ligands can introduce additional functionalities to the coordination sphere around the metal centre, resulting in a metal-ligand drug synergism [3235]. Therefore, it becomes apparent that half-sandwich arene ruthenium complexes will allow introduction of numerous biologically active groups. Among the first ruthenium(II) arene complexes reported is $\left[\mathrm{Ru}\left(\eta^{6}-\mathrm{C}_{6} \mathrm{H}_{6}\right)(\mathrm{DMSO}) \mathrm{Cl}_{2}\right](\mathbf{4 a})$ (Figure 3). Investigations into its antitumor potential revealed that the complex strongly inhibits the function of topoisomerase II, which is important for structural organization of the mitotic chromosomal scaffold during cell replication process [36]. 


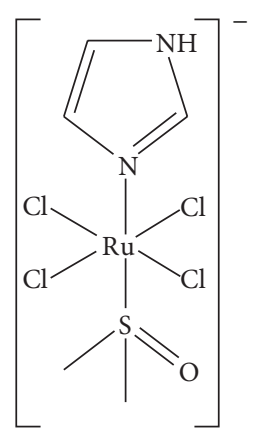

(1)

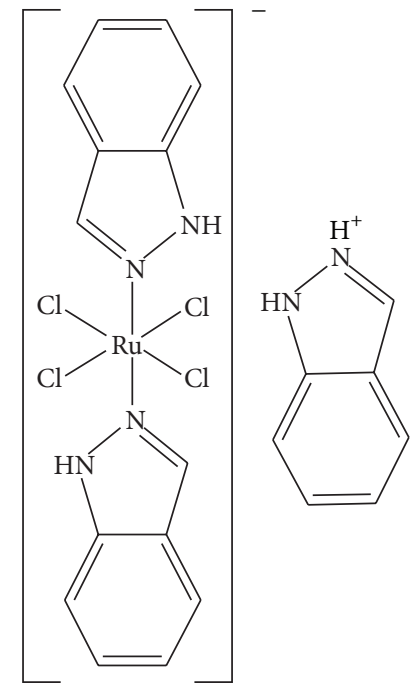

(2a)

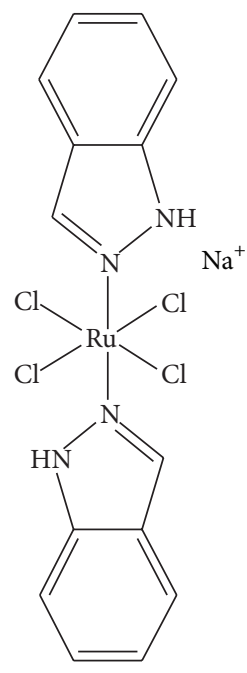

(2b)

Figure 1: Structures of Ru(III) complexes: NAMI-A (1), KP1019 (2a), and NKP-1339 (2b).

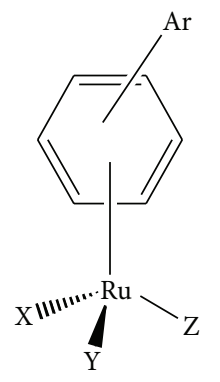

(3)

FIGURE 2: General structure of Ru(II) complexes with "piano-stool” configuration.

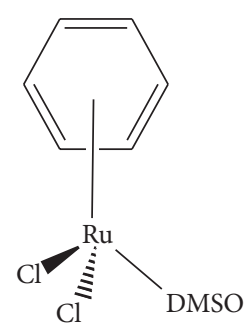

(4a)
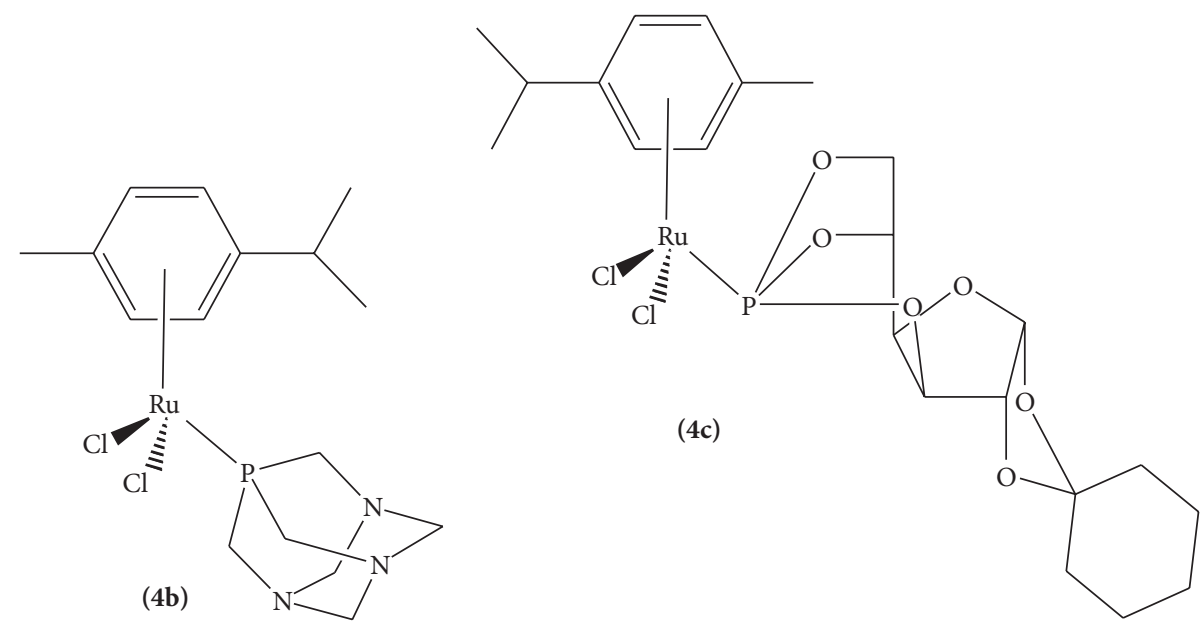

FIgURE 3: Structures of $\mathrm{Ru}(\mathrm{II})$ arene complexes $\left[\mathrm{Ru}\left(\mathrm{C}_{6} \mathrm{H}_{6}\right)(\mathrm{DMSO}) \mathrm{Cl}_{2}\right](\mathbf{a})$, RAPTA-C (b), and KP1558 (c). 


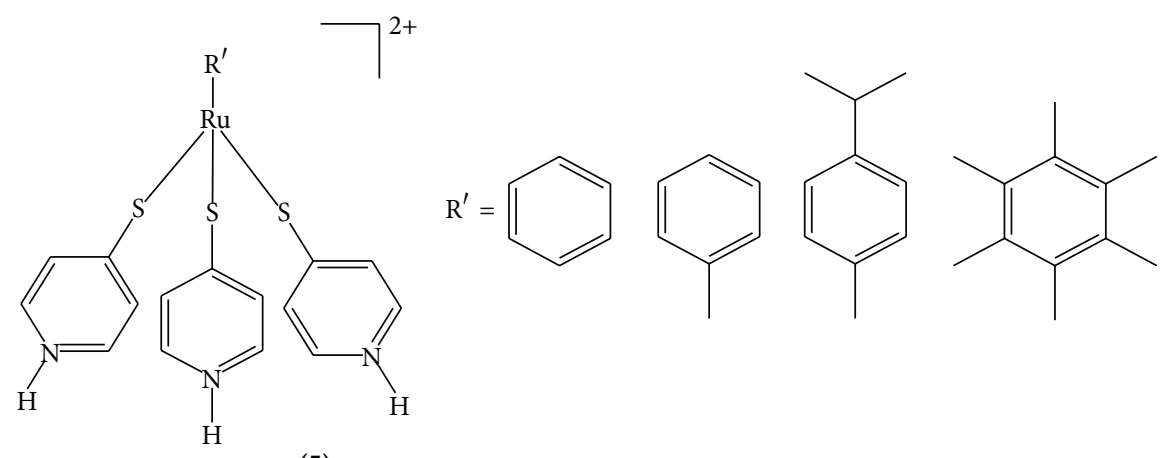

(5)

FIgURE 4: Ruthenium(II) complexes containing pyridinethiolato ligands.

Scolaro et al. has shown that when DMSO molecule in compound $\mathbf{4 a}$ was replaced by PTA (1,3,5-triaza-7-phosphatricyclo[3.3.1.1]decane) this ligand exchange increased aqueous solubility of the new complex RAPTA-C (4b), thereby giving rise to promising antimetastatic activities, high selectivity, and generally low toxicity which makes them attractive as potential therapeutic agents [37]. It is therefore strongly believed that PTA ligand is responsible for the observed selectivity. Furthermore, methylation of one PTA nitrogen leads to a further increase in toxicity $[37,38]$. The compound was found to be noncytotoxic in the metastasizing mouse cell lines TS/A or human HBL100 (breast carcinoma) cell line but showed pronounced antimetastatic activity. Crystallographic experiments of $\mathbf{4 b}$ with the nucleosome core showed that proteins are the primary target of the compound $[37,38]$.

Another compound KP1558 (4c) (Figure 3) and its analogues are prepared by replacing PTA with 3,5,6-bicyclophosphite- $\alpha$-D-glucofuranoside ligands to obtain highly active compounds $[39,40]$. The lipophilicity of the complexes can be modulated by modifying the carbohydrate moiety to yield coordination compounds with high aqueous solubility ideally suited for intravenous administration or hydrophobic species that facilitate cellular uptake. The hydrolytic behaviour, the affinity to proteins and model nucleobases, and the in vitro antineoplastic activity of the complexes were investigated against human SW480 (colon adenocarcinoma), CH1 (ovarian cancer), cisplatin-resistant A2780 (ovarian carcinoma), A549 (lung carcinoma), Me300 (melanoma), LNZ308 (glioblastoma), and HCEC (endothelial) cell lines $[39,40]$. In water, the phosphite ligand is hydrolyzed, and this process is activated by prior hydrolysis of the chlorido ligand at the ruthenium centre. The complex resulting from hydrolysis of the $\mathrm{Ru}-\mathrm{Cl}$ bonds and $\mathrm{P}-\mathrm{O}$ bonds of the ligand showed affinity towards albumin and transferrin, and it was also capable of binding to 9-ethylguanine (9EtG) with formation of $1: 1$ adducts. The complexes showed remarkably high activity in all tested cell lines, and cytotoxic activity of the compounds is believed to be enhanced by the alkyl moiety of the phosphite which makes the compound more lipophilic $[39,40]$.

Arene ruthenium(II) complexes containing pyridinethiolato ligands (5) have been subject of investigation due to their remarkable in vitro cytotoxicity profile (Figure 4) [41]. The work was motivated by previous reports on platinum complexes containing pyridinium-thiolato ligands, which demonstrated excellent anticancer activity [42]. The mononuclear ruthenium complexes $\left[\left(\eta^{6}\right.\right.$-arene $)$ $\left.\mathrm{Ru}\left(\mathrm{SC}_{5} \mathrm{H}_{4} \mathrm{NH}\right)_{3}\right]^{2+}$ are prepared by reaction of dinuclear arene ruthenium complexes $\left[\left(\eta^{6} \text {-arene }\right)_{2} \mathrm{Ru}_{2}\left(\mu_{2}-\mathrm{Cl}\right)_{2} \mathrm{Cl}_{2}\right]$ (arene $=\mathrm{C}_{6} \mathrm{H}_{6}, \mathrm{C}_{6} \mathrm{H}_{5} \mathrm{Me}, p-{ }^{i} \mathrm{PrC}_{6} \mathrm{H}_{4} \mathrm{Me}, \mathrm{C}_{6} \mathrm{Me}_{6}$ ) with 4-pyridinethiol. The reaction formally involves the transfer of the hydrogen atom in 4-pyridinethiol from sulfur to nitrogen to form a 4-pyridinium-thiolato ligand [41]. The redox data of the complexes shows that the complexes generally undergo two consecutive irreversible oxidations. However, there is no clear correlation between the $\mathrm{IC}_{50}$ values against human A2780 (ovarian cancer) cells and the $E_{\mathrm{pa}}$ data, since the benzene derivative is more cytotoxic compared to the alkyl-substituted arene derivatives. The hexamethylbenzene derivative is the most cytotoxic, and it is worth noting that the observed cytotoxic values are superior to those of cisplatin and other platinum-based agents [41].

In an attempt to overcome multidrug resistance, arene ruthenium complexes of the general formula $\left[\mathrm{Ru}\left(\eta^{6}-p\right.\right.$ cymene) $\mathrm{Cl}_{2}(\mathrm{~L})$ ] (6-8) have been explored ( $\mathrm{L}=$ anthracenebased multidrug resistance modulator ligands) (Figure 5) [43]. The general toxicity test of complexes $\mathbf{6 - 8}$ shows that $\mathbf{8}$ is the most active while $\mathbf{6}$ is the least cytotoxic substance. Compound $\mathbf{8}$ provides a relatively homogeneous cytotoxicity profile across all the examined cell lines, showing similar activity in all tumorigenic cell lines and the nontumorigenic human cell line HBL-100 (breast carcinoma), which could indicate a generalized mechanism of action. Further studies on 8 show that it induces cell death via inhibition of DNA synthesis. Since the complex is fluorescent, its uptake in cells was studied, and relative to the free anthracene-based ligand, uptake of the complex is accelerated and accumulation of the complex in the cell nucleus is observed. Interestingly, 6 exhibits highly cytotoxic properties in human HT-29 (colon adenocarcinoma) cells only, but its selectivity towards a certain type of cancer makes it a promising compound [43].

A recent report based on excellent in vitro anticancer activity of long-chain isonicotinic ester ruthenium(0) nanoparticles [44] motivated the group of Khan et al. to 

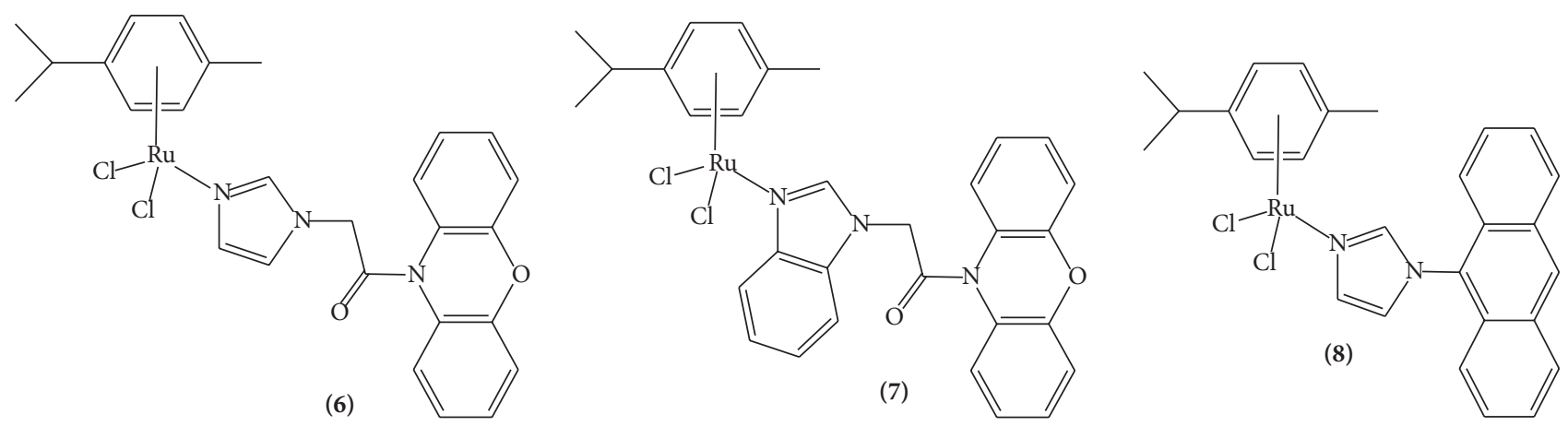

Figure 5: Ruthenium(II) complexes of the general formula $\left[\mathrm{Ru}\left(\eta^{6}-p\right.\right.$-cymene $\left.) \mathrm{Cl}_{2}(\mathrm{~L})\right]$.

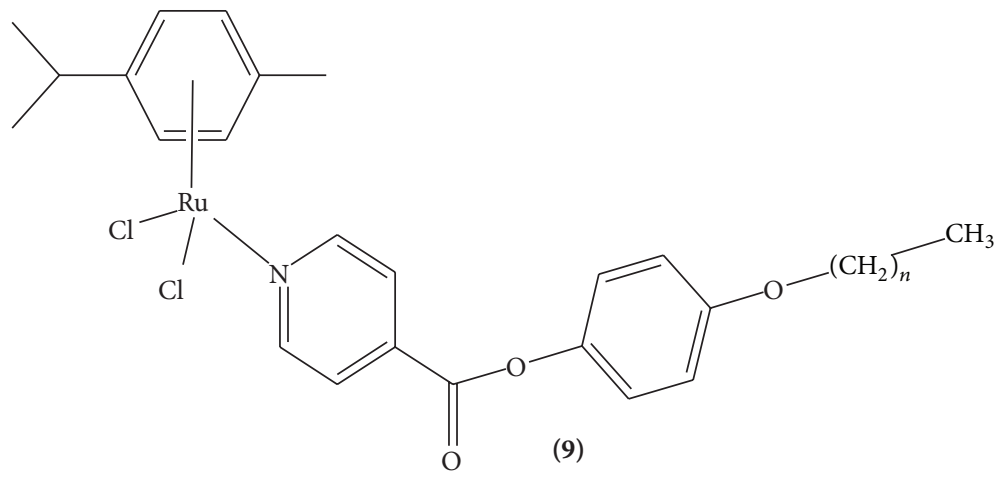

FIgURE 6: Arene ruthenium dichloro complexes containing isonicotinic ester ligands.

adopt long-chain isonicotinic esters in their ligand backbone as lipophilic components, with a view to increase anticancer activity of their arene ruthenium complexes [45]. The work eventually led to the development of a series of $p$ cymene ruthenium dichloro complexes containing isonicotinic ester ligands, $\left[\left(\eta^{6}\right.\right.$-arene) $\mathrm{RuCl}_{2} \mathrm{NC}_{5} \mathrm{H}_{4}-4-\mathrm{COO}-\mathrm{C}_{6} \mathrm{H}_{4}$ $p$-O- $\left.\left(\mathrm{CH}_{2}\right)_{n}-\mathrm{CH}_{3}\right](n=1,3,5,7,9,11,13,15)(9)$ from $p$ cymene ruthenium dichloro dimer, and the corresponding isonicotinic ester ligand (Figure 6). The molecules adopt a pseudotetrahedral piano-stool geometry, while the isonicotinic ester ligand is coordinated through the nitrogen atom. Isonicotinic acid (pyridine-4-carboxylic acid) is widely used for the synthesis of antibiotics and antituberculosis preparations [46]. This encouraging pharmacological profile of isonicotinic acid derivatives coupled with amphiphilic arene ruthenium moieties makes this combination desirable for drug design. The $p$-cymene ruthenium dichloro complexes were evaluated for anticancer activity towards human A2780 (ovarian carcinoma) and A2780cisR (ovarian carcinoma, cisplatin resistant) cells, and high activities were observed only for $n=9$ (presenting a chain with ten carbon atoms) [45].

There is remarkable prospective among ruthenium half-sandwich structured complexes with cyclopentadienyl ligands [47-49]. The aromatic ligand $\eta^{5}-\mathrm{C}_{5} \mathrm{H}_{5}$ occupies three coordination positions, thereby offering stability to the metal centre [47]. As expected for potentially active ruthenium halfsandwich compounds, the remaining coordination sites can be occupied by a ligand that could impart antitumor activity together with ligands that can control electronic properties at the ruthenium centre [47]. Molecular structures of many of these compounds were successfully solved by X-ray crystallography. Garcia et al. first reported biological studies of compounds containing the "RuCp" fragment $\left(\mathrm{Cp}=\eta^{5}\right.$ cyclopentadienyl) with heteroaromatic ligands (10) (Figure 7) [49]. A dose response of each compound was performed in human LoVo (colon adenocarcinoma) and Mia-PaCa (pancreatic) cell lines, and both compounds caused a significant effect in cell viability in the nanomolar range. The complex with pyridazine $(\mathbf{1 0 b})$ produced a decrease of cell survival of more than $90 \%$ at $500 \mathrm{nM}$ in both cell lines, whereas the complex with triazine (10a) was less effective [49]. Atomic force microscopy (AFM) images suggest different mechanisms of interaction with the plasmid pBR322 DNA, while the mode of binding of the compounds could be intercalation between base pairs of DNA (10a) or covalent bond formation with $\mathrm{N}$ from the purine base (10b) [49]. The $\mathrm{IC}_{50}$ values derived from these compounds are within the lowest $\mathrm{IC}_{50}$ values in half-sandwich stool ruthenium complexes reported elsewhere [50, 51].

Moreno et al. further explored cytotoxic properties of compounds of general formula $\left[\mathrm{Ru}\left(\eta^{5}-\mathrm{C}_{5} \mathrm{H}_{5}\right)(\mathrm{PP}) \mathrm{L}\right]^{+}(11$ and 12), where $\mathrm{L}$ is a $\mathrm{N}$-heteroaromatic $\sigma$-bonded ligand, chosen within planar molecules, in order to potentiate intercalation of compounds in DNA, besides their possible covalent binding to N7 guanine residues (Figure 7) [48]. They observed 


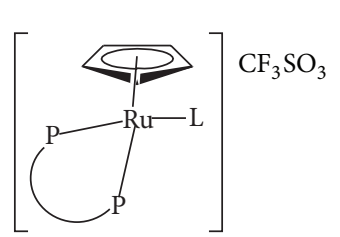

$\mathrm{PP}=$ dppe, $\mathrm{L}=$ triazine $(\mathbf{a})$ $\mathrm{PP}=2 \mathrm{PPh}_{3}, \mathrm{~L}=$ pyridazine $(\mathbf{b})$

10

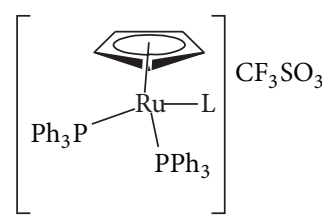

11

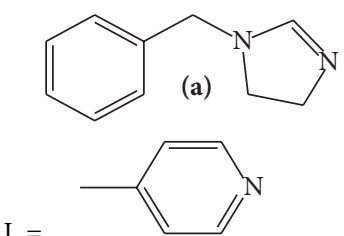

(b)<smiles>c1ccc(-c2ccccn2)nc1</smiles>

(c)

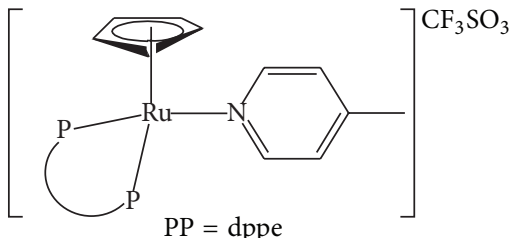

12
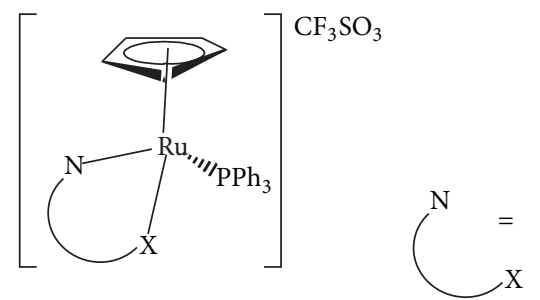<smiles>O=C(c1ccccc1)c1ccccn1</smiles><smiles>CC(=O)c1ccccn1</smiles>

$\mathrm{X}=\mathrm{O}, \mathrm{N}$<smiles>O=C(c1ccccc1)c1nccc2ccccc12</smiles>

(c)<smiles>O=C(c1ccccn1)c1ccccn1</smiles>

(d)

FIGURE 7: Ruthenium-cyclopentadienyl complexes with heteroatomic ligands.

interesting properties of stability in addition to the excellent cytotoxicity in $\mathrm{Ru}\left(\eta^{5}-\mathrm{C}_{5} \mathrm{H}_{5}\right)$ systems coordinated to $\mathrm{N}$ heteroatomic molecules, thereby suggesting the effectiveness of a chelating ligand [48]. Their investigation mainly focused on different hapticity of L, which can be monodentate, such as 1-benzylimidazole (11a), 4-methylpyridine (11b), or 2,2' bipyridyl (11c), occupying two coordination sites, leading to a different mechanism of action of the complexes [48]. Compound $\mathbf{1 2}$ had a bidentate phosphine ligand to check if there would be significant difference in cytotoxicity profile of the complex compared to $11 \mathbf{b}$. Interaction of these new compounds with the plasmid pBR322 DNA was studied by AFM, electrophoretical mobility, and viscosity measurements, and their cytotoxicity was examined on human HL60 (leukemia cancer) cells [48]. Generally, cytotoxicity of the compounds was much higher than that found in cisplatin against human HL-60 (leukemia cancer) cells, thereby indicating that, for these type of ruthenium compounds, DNA is possibly one of the targets of their action inside the cells [48]. Further biological studies were performed by incubating the compounds with free plasmid pBR322 DNA and pBR322 DNA, and the resulting images obtained by
AFM showed several supercoiled forms of plasmid DNA strongly modified, which could suggest interaction with plasmid DNA [48]. The interaction was further confirmed by viscosity measurements of solutions of free DNA and DNA incubated with different concentrations of the compounds. The complexes contain 1-benzylimidazole ligand or phenyl groups on the two phosphine ligands which are capable of intercalation between base pairs of DNA [48].

This architectural friendliness observed in half-sandwich arene ruthenium complexes offers an opportunity to improve their cytotoxic profiles [47]. The complexes were prepared by $\sigma$ coordination of ligands L, presenting two heteroatoms, 2benzoylpyridine (13a), 2-acetylpyridine (13b), 1-isoquinolinyl phenyl ketone (13c), and di(2-pyridyl)ketone (13d). The compounds presented coordination sites other than nitrogen, and they proved to be very stable when exposed to air and moisture [47]. Experimental data $\left({ }^{1} \mathrm{H},{ }^{13} \mathrm{C} \mathrm{NMR}\right.$, UV-vis, and DFT theoretical calculations) of these compounds revealed that metal-ligand binding was strengthened by an electronic flow from the metal centre to the $\sigma$ bonded ligand [47]. Cytotoxic studies in human A2780 (ovarian carcinoma), A2780cisR (ovarian carcinoma, cisplatin 


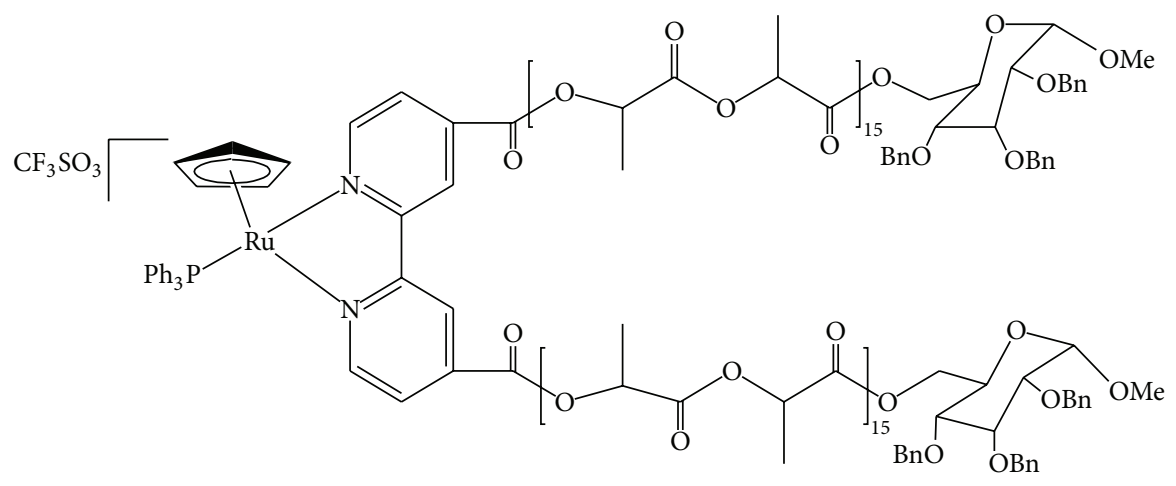

(14)

FIGURE 8: D-glucose end capped polylactide ruthenium-cyclopentadienyl.

resistant), MCF-7 (breast adenocarcinoma-hormone dependent), MDAMB231 (hormone-independent breast adenocarcinoma), HT-29 (colon adenocarcinoma), and PC3 (prostate cancer) cell lines revealed an exceptional activity of the complexes, with $\mathrm{IC}_{50}$ values in the nanomolar range [47]. However, the isoquinolinyl moiety in complex $13 \mathrm{c}$ seemed to reduce its cytotoxic activity when compared with $\mathbf{1 3 a}, \mathbf{1 3} \mathbf{b}$, and $\mathbf{1 3 d}$. Despite compound $\mathbf{1 3 c}$ ranking as the least active complex, it still presented higher cytotoxic activity than the reference drug cisplatin even for the more chemioresistant cancer cells PC3 [47]. Further biological studies are yet to be carried out to highlight the potential of these compounds as future drugs considering that cytotoxicity is not exclusive for determining suitability of metallodrugs.

Recently, Valente et al. reported on the first polymer based ruthenium-cyclopentadienyl complex [CpRu(P)(bpyPLA) $]^{+}$ (14) $(\mathrm{Cp}=$ cyclopentadienyl, $\mathrm{P}=$ triphenylphosphine, and bpyPLA $=2,2^{\prime}$-bipyridine- $4,4^{\prime}$-D-glucose end-capped polylactide), which demonstrated potential as anticancer agent (Figure 8) [52]. The work was motivated by earlier findings which revealed how polymeric controlled drug delivery could prove to be a promising alternative to the conventional drug delivery approaches in cancer therapy [53]. A degradation study of the complex in HEPES (4-(2hydroxyethyl)-1-piperazineethanesulfonic acid) buffer was performed to investigate the polymer hydrolysis at physiological and tumour cell $\mathrm{pH}$. Results showed that the complex is stable over some days in an aqueous environment at physiologic $\mathrm{pH}$ [52]. Cytotoxicity of compound 14 was assayed in human MCF-7 (breast adenocarcinoma-hormone dependent) and MDAMB231 (hormone-independent breast adenocarcinoma) and A2780 (ovarian adenocarcinoma) cell lines, and the compound proved to be 6-fold more cytotoxic compared to cisplatin especially for the MCF-7 cell lines, thereby supporting the initial suggestion that polymer ruthenium-cyclopentadienyl complexes could soon replace the known anticancer agent [52]. Further tests on cellular distribution of the complex, carried out using inductively coupled plasma mass spectrometry (ICP-MS), showed that higher amount of ruthenium localized in the nucleus than in the membrane, therefore representing high uptake of ruthenium by cells. The results possibly suggest DNA as the potential target for ruthenium-cyclopentadienyl complexes [52].

Although ruthenium-cyclopentadienyl compounds bearing carbohydrate-derived ligands remain an unexplored area, there is emerging evidence of their application as antitumor agents. For example, new $\eta^{5}$-cyclopentadienyl ruthenium(II) complexes of general formula $\left[\left(\eta^{5}-\mathrm{C}_{5} \mathrm{H}_{5}\right) \mathrm{Ru}(\mathrm{PP})(\mathrm{L})\right]^{+}$, isolated as $\mathrm{PF}_{6}{ }^{-}$salts, have been reported [54], where L represents the galactose and fructose carbohydrate derivative ligands, functionalized with nitrile, tetrazole, and 1,3,4oxadiazole N-coordinating moieties (15a-c) (Figure 9) [54]. Electronic density and the stereochemical environment of the metal centre are controlled by using two different phosphanes, $\mathrm{PPh}_{3}$ and dppe, used as coligands. Cytotoxic studies on human HeLa (cervical carcinoma) cancer cell lines revealed very good activities, with $\mathrm{IC}_{50}$ values in the low micromolar range, better than cisplatin. However, further work is yet to be carried out on their cellular transport distribution and possible mode of action [54].

The presence of a chelating ligand in the half-sandwich ruthenium(II) complexes appears to offer advantages of structural stability and the opportunity to "fine-tune" the electronics of the ruthenium centre, which is an important parameter for drug development [5, 55-62]. The tuning of the ligand also results in a changed preference of the targeted nucleobases. Based on this background, a group of ruthenium(II) arene complexes containing diamine moieties in the coordination sphere (16) has been reported (Figure 10). The complexes contain chelating bidentate ligands such as ethylenediamine [55-60], paullones (17 and 18) (Figure 11) [61], and staurosporine (where the $\pi$-arene is a cyclopentadienyl, Cp) (19) inserted into the ruthenium scaffolds (Figure 12) [5, 55-60, 62]. According to the rules governing structure-activity relationships for an effective platinum anticancer drug, the two nonleaving cis-coordinated amine ligands are crucial for anticancer activity [63]. These rules would also apply to ruthenium compounds.

These ethylenediamine based complexes exhibit high in vitro and in vivo anticancer activities against human ovarian A2780 cell lines. The complexes bind coordinatively to N7 of guanine in DNA, which can be complemented by intercalative binding of an extended arene and specific hydrogen 

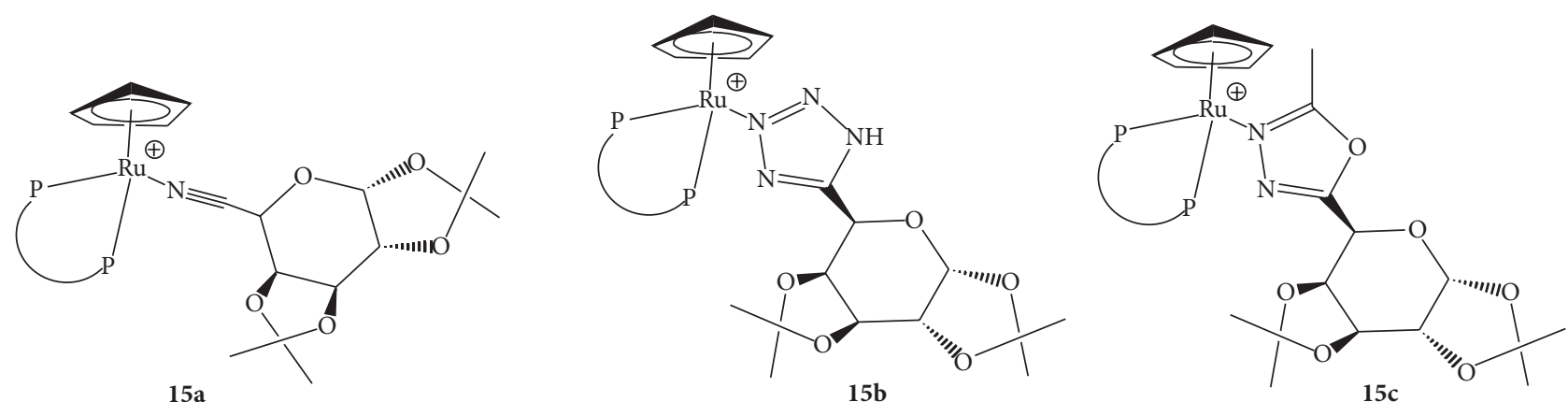

FIGURE 9: Ruthenium-cyclopentadienyl complexes with carbohydrate-derived ligands.

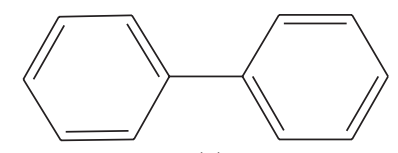

(a)

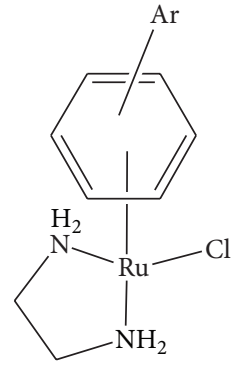

(16)<smiles>c1ccc2c(c1)Cc1ccccc1C2</smiles>

(b)<smiles>C1=CCC2=C(C1)Cc1ccccc1C2</smiles>

(c)

FIGURE 10: Structures of ethylenediamine based $\mathrm{Ru}(\mathrm{II})$ complexes with isonicotinic ester ligands benzene derivatives.

bonding interactions of the ethylenediamine $\mathrm{NH}_{2}$ groups with $\mathrm{C6O}$ of guanine [55-60]. These additional interactions result in unique binding modes to duplex DNA and induce different structural distortions in DNA compared to cisplatin, which explains why these complexes are not cross-resistant with cisplatin [64]. Among these ethylenediamine based arene ruthenium complexes, compound 16a has proved to be a lead, by demonstrating p53 and p21/WAF1-dependent early growth arrest in HCT116 (colorectal cancer) cell lines [65]. The paullones, known as cyclin-dependent kinase (CDK) and glycogen synthase kinase-3 inhibitors, contain a seven-member folded azepine ring, which makes the molecule nonplanar [61]. The complexes were investigated for their antiproliferative activity against A529 (non-small lung cancer) cell, CH1 (ovarian carcinoma), and SW480 (colon adenocarcinoma), where they exhibited cytotoxic activities that were in the micromolar concentration range, therefore showing great potential as antitumor agents. This work was immediately followed by the development of arene ruthenium(II) indoloquinoline complexes (20) (Figure 13) with a view to elucidate the structure-activity relationship of these compounds [64]. The complexes have a similar framework to the paullones but have a six-membered ring. Binding of indoloquinolines to a metal-arene scaffold is believed to make the products soluble enough in biological media to allow for assaying their antiproliferative activity [64]. Their cytotoxic profiles were observed to be higher than their paullone counterparts in the three human cancer cell lines. These complexes were later modified by introducing a methyl and halo substituents in position 8 of the molecule backbone (21) (Figure 13) [65]. However, the complexes have a five-membered ring. The effect of substituents in position 8 of the indoloquinoline backbone had been previously investigated on copper(II) complexes, where they returned cytotoxic values in the nanomolar concentration range [66]. The arene ruthenium(II) indoloquinoline compounds with halo substituents in position 8 were found to be more effective cytotoxic agents in vitro than the previously reported species halogenated in position 2 of the indoloquinoline backbone as expected [65].

Staurosporine type complexes (19) were initially explored by Meggers et al. with a view to develop efficient and economical synthetic strategy for the rapid modification of the cyclopentadienyl moiety of ruthenium half-sandwich protein kinase inhibitors [55-60]. They adopted half-sandwich strategy and inserted a ligand derived from the kinase inhibitor to the ruthenium coordination sphere [55-60]. The approach has led to the identification of Pim-1 and GSK-3R inhibitors with improved potencies and selectivities. Before coordination, natural staurosporine has a useful property 


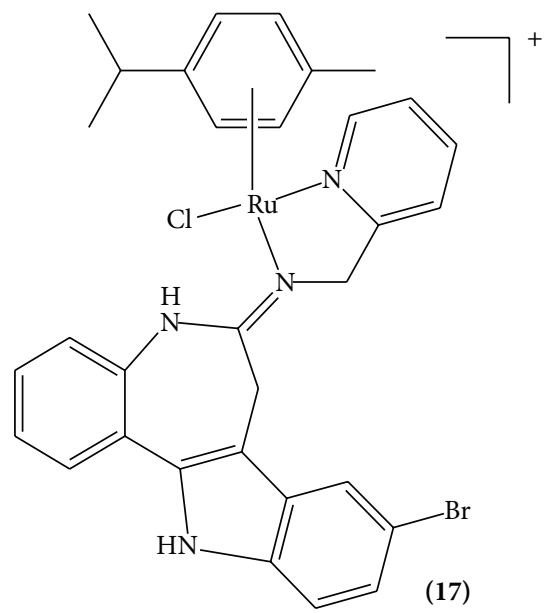

$\mathrm{Cl}^{-}$

FIGURE 11: Some paullone-type arene ruthenium(II) complexes.

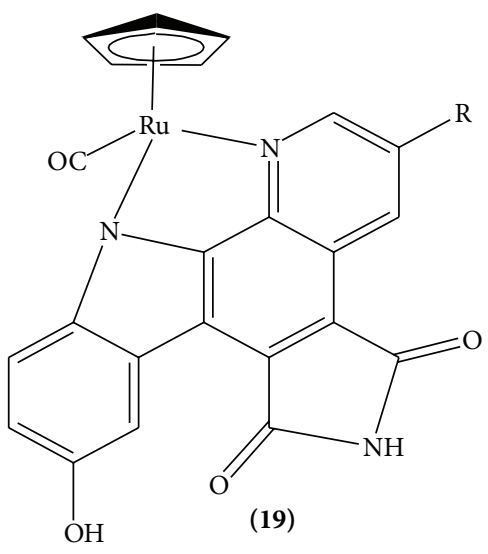

FIGURE 12: Staurosporine-type arene ruthenium complexes.

of inhibiting various kinases, which has led to the development of many anticancer drugs based on staurosporine derivatives. However, recent research has shown that the activity of the ligands becomes more pronounced when they are coordinated to the metal [67]. The strategy of designing metal complexes as protein kinase inhibitors using staurosporine as a lead structure was therefore aimed at mimicking the binding mode of staurosporine [55-60]. The approach was based on the hypothesis that complementing an organic scaffold with a metal center opens new avenues for the design of small molecules with novel threedimensional structures and thus offers an opportunity to develop compounds with novel biological properties [55-60]. The metal complexes bear a bidentate ligand which retains the structural features of the indolocarbazole heterocycle and the approach targets the metal complexes to the ATPbinding site [55-60]. The remaining ligand sphere of the ruthenium atom gives the opportunity to create interactions with other parts of the ATP-binding site. Meggers et al. have already proved that the ligand sphere around the ruthenium centre substantially influences kinase binding affinities [5560]. It is therefore not surprising that staurosporine type arene ruthenium(II) complexes tested against melanoma cell lines gave nanomolar activity [68]. The complexes are potent activators of $\mathrm{p} 53$ proteins and induce $\mathrm{p} 53$ activated apoptosis via mitochondrial pathway [55-60]. At the same time, these new scaffolds have other properties which are clearly distinct from their parent indolocarbazole alkaloids. For example, whereas staurosporine is a nanomolar inhibitor for most protein kinases, some racemic mixtures of ruthenium halfsandwich compounds show a remarkable preference for just a few kinases like GSK-3 and Pim-1, thereby demonstrating improved selectivity [55-60].

Research has demonstrated that arene ruthenium(II) complex $\left[\left(\eta^{6} \text {-arene }\right) \mathrm{Ru}^{\mathrm{II}}(\mathrm{en}) \mathrm{Cl}\right]^{+}$, which exhibits great inhibitory activity against various human tumor cells, can unwind the double-strand helix of DNA by forming monofunctional adducts with DNA in intercalative mode $[69,70]$. Furthermore, cell cycle arrest in G1 phase through p53dependent and p53-independent mechanism has also been reported for these compounds [71]. However, the little available information on the S-phase cell cycle arrest through DNA damage-mediated p53 phosphorylation induced by arene ruthenium complexes has prompted $\mathrm{Wu}$ et al. to study 


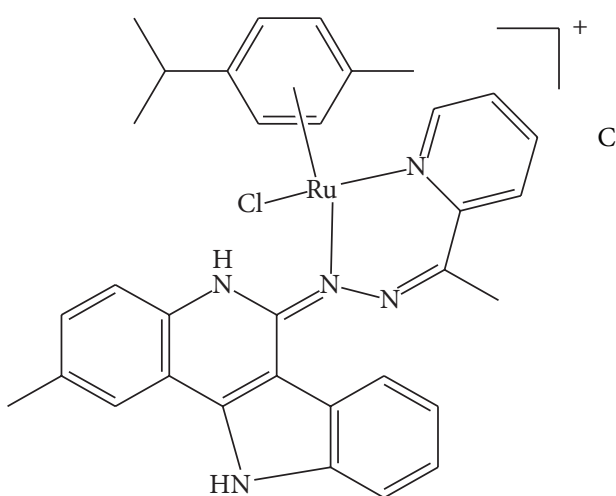

(20)

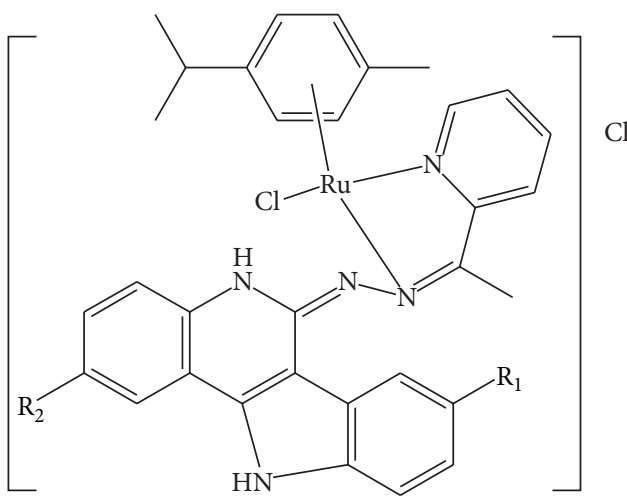

(21)

$$
\begin{aligned}
& \mathrm{R}_{1}=\mathrm{Cl}, \mathrm{Br} \\
& \mathrm{R}_{2}=\mathrm{CH}_{3}
\end{aligned}
$$

FIGURE 13: Indoloquinoline type arene ruthenium(II) complexes.

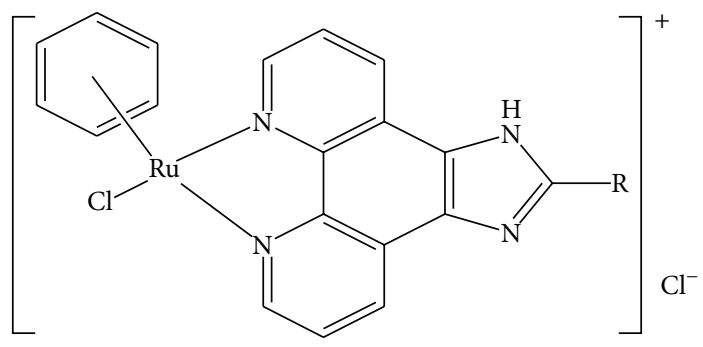

(22)

FIGURE 14: Arene ruthenium(II) complexes coordinated by phenanthroimidazole derivatives.

a series of arene ruthenium(II) complexes coordinated by phenanthroimidazole derivatives (22) (Figure 14) [72]. The complexes displayed acceptable inhibitory activity against various tumour cells, especially human MG-63 (osteosarcoma) cells. The complexes also bind to DNA molecule by intercalative mode to disturb the biofunction of tumor cells. Further investigation on the mechanisms revealed that this type of arene ruthenium(II) complexes could induce S-phase arrest in tumor cells through DNA damage-mediated p53 phosphorylation [72].

Several other ruthenium based compounds containing chelating pyrone $(\mathrm{O}, \mathrm{O})$ and thiopyrone $(\mathrm{S}, \mathrm{O})(\mathbf{2 3})$ (Figure 15) $[73,74]$ and tetrahydroisoquinoline $(\mathrm{N}, \mathrm{O})(\mathbf{2 4})$ (Figure 16) moieties [75] have been prepared with a view to study the ruthenium-ligand interaction and its effect on the in vitro anticancer activity. The thiopyrones are reported to be more lipophilic than their pyrone analogues. Fernández and coworkers have demonstrated that a change of donor ligand has a profound effect on the electronic properties of the $\mathrm{Ru}$ (II) complex [76]. Antiproliferative activities of type $\mathbf{2 3}$ compounds were investigated against the colon carcinoma SW480 and ovarian carcinoma CH1 cancer cell lines, and the thiopyrone complexes were more active compared to their pyrone analogues. DFT calculations show that thiopyrones have stronger binding to ruthenium compared to pyrones, and the different stabilities of these compounds may be responsible for the observed influence of the donor atoms on in vitro anticancer activity [75]. Ruthenium(II) arene complexes bearing 1,2,3,4-tetrahydroisoquinoline (TIQ) amino alcohol ligands (24) have been investigated for their activity against human cancer cell lines MCF-7, A549 (lung adenocarcinoma), MDAMB-231 (hormone-independent breast adenocarcinoma), and normal MDBK cells [75]. Synthetic TIQ derivatives have been found to exhibit interesting biological activities which range from histidine $\mathrm{H} 3$ antagonism, antidiabetic activity, and multidrug resistance reversal for some identified cancers [77-79]. These remarkable properties suggest that incorporation of the TIQ moiety as a backbone in metal complexes could be a viable anticancer drug discovery strategy [75]. The complexes are inactive against the A549 and MDAMB-231 cell lines. However, they exhibited moderate activity against MCF-7 cancer cells with $\mathrm{IC}_{50}$ values ranging from 34 to $218 \mu \mathrm{M}$, a surprising observation because the compounds differ by only one diastereomeric centre. The most fascinating result was the remarkable selectivity displayed for MCF-7 cells in comparison to normal MDBK cells [75].

Anticancer activities of ruthenium(II) compounds based on N-substituted 2-pyridinecarbothioamides (PCAs) (25) have been documented in the literature (Figure 17) [80]. The 2-pyridinecarbothioamide ligands have previously shown notable activity as gastric mucosal protectants and low acute toxicity in vivo [81]. However, their coordination 


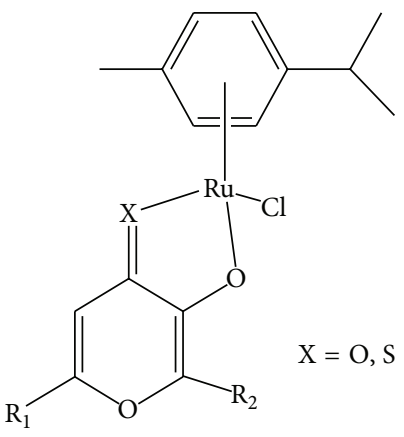

(23)

Figure 15: Pyrone and thiopyrone ruthenium(II)-cymene complexes.

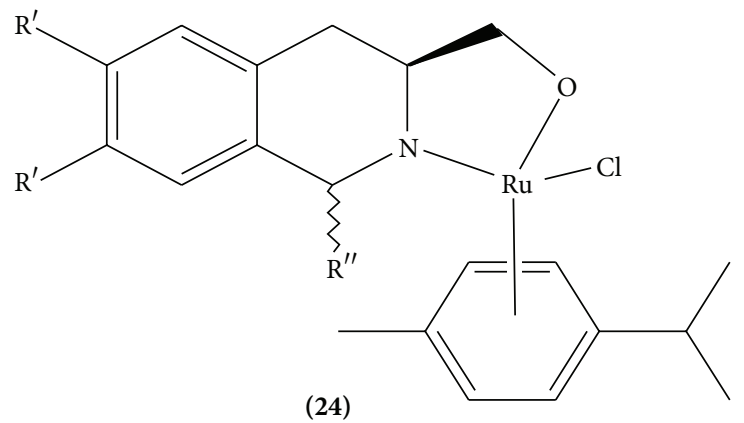

FIGURE 16: Ruthenium(II) arene complexes bearing TIQ amino alcohol ligands.<smiles></smiles>

(25)

FIGURE 17: Ruthenium(II) complexes of N-substituted 2-pyridinecarbothioamides.

to ruthenium(II) yielded highly cytotoxic agents in the more chemoresistant SW480 (colon adenocarcinoma) and A549 cell lines. The complexes boast exceptional stability in hydrochloric acid, coupled with low reactivity towards biological molecules. Their unexpected aqueous chemistry renders them suitable for oral administration. Crystallographic studies with the nucleosome core revealed that the compounds form exclusively histidine-adducts, while being devoid of DNA binding [80].

2.2. Inorganic Ruthenium(II) Compounds. Ruthenium complexes containing arylazopyridine (azpy) ligands have attracted attention. Three of the possible five isomers of
$\left[\mathrm{Ru}(\text { azpy })_{2} \mathrm{Cl}_{2}\right](\alpha(\mathbf{2 6 a}), \beta(\mathbf{2 6 b})$ and $\gamma(\mathbf{2 6 c}))$ have been reported, where the $\alpha$ isomer represents cis,trans,cis, the $\beta$ isomer cis,cis,cis, and the $\gamma$ isomer trans,cis,cis positions of the chlorides, the pyridine, and azo nitrogens, respectively (Figure 18) [82, 83]. The compounds show promising cytotoxic activity that is structurally dependent ( $\alpha$ and $\gamma$ isomers show higher toxicities than the $\beta$ isomer). DFT calculations suggest that the ability of the isomers to intercalate to DNA decreases from $\gamma>\alpha>\beta$ isomers on the basis of the geometric and electronic factors, and this supports the observed cytotoxicity [84].

A similar compound to $\left[\mathrm{Ru}(\text { azpy })_{2} \mathrm{Cl}_{2}\right]$, the trans- $\left[\mathrm{Ru}^{\mathrm{II}}\right.$ $\left.(\text { Hpyrimol })_{2} \mathrm{Cl}_{2}\right]$ (Hpyrimol = 4-methyl-2-N (2-pyridyl- 


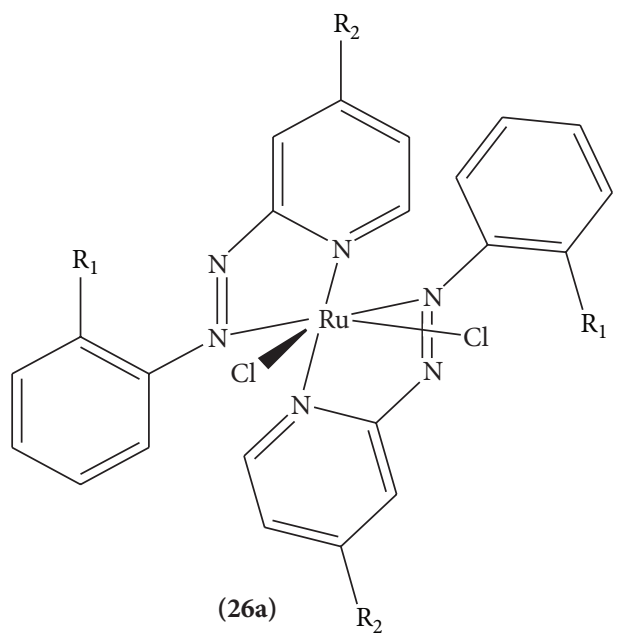

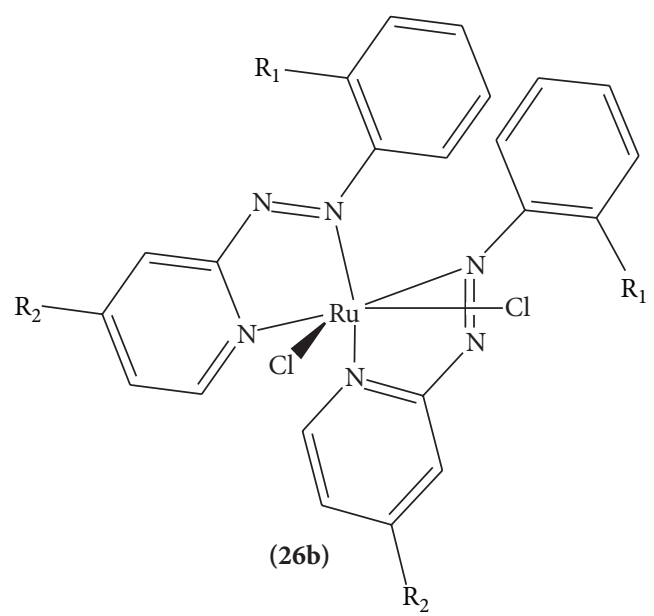

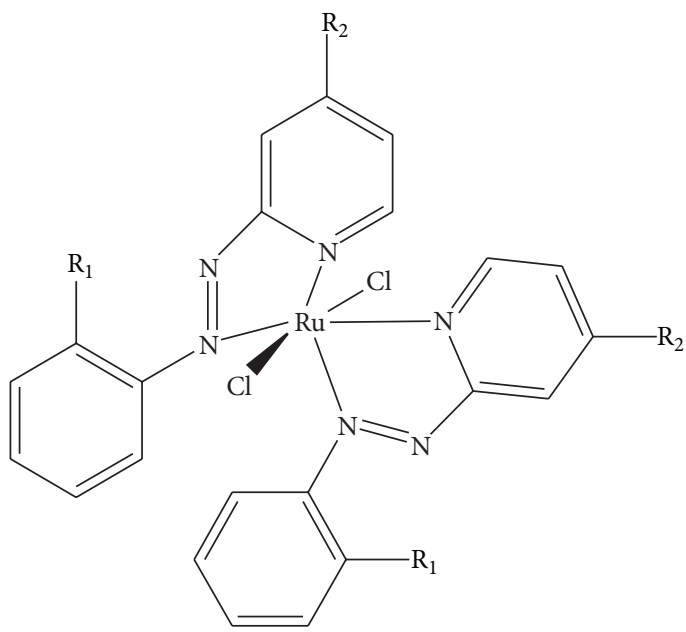

(26c)

FIGURE 18: Representation of the three isomeric arylazopyridine ruthenium(II) complexes.

methylene) aminophenol) (27), has been synthesised and studied in detail to explore its DNA binding and cleaving properties (Figure 19) [85]. The coordinated neutral ligand Hpyrimol is formed through ligand dehydrogenation of the redox-active ligand Hpyramol. Although the ligand is potentially tridentate and anionic, the coordination motif of Hpyrimol is bidentate, as a N,N-donor and a noncoordinated neutral phenol group. Interestingly, when starting from $\mathrm{Ru}$ (III) chloride, a $\mathrm{Ru}$ (II) compound is formed, in which the ligand Hpyrimol remains neutral and chelates as a bidentate ligand. The neutral phenol groups form stable intramolecular hydrogen bonds with the coordinated chloride anions [85].

Not only does compound 27 bind to DNA, but also it additionally cleaves DNA via single-strand cutting. In the DNA-interaction studies, hypochromism is observed with increasing amounts of DNA in the reaction mixture, indicating intercalative binding of the ruthenium compound between the DNA base pairs $[86,87]$. Although the compound is not a planar molecule, it may intercalate partially using the ligand surface to slide into the DNA base pairs. An in vitro cytotoxicity assay shows that the compound is quite active and even comparable to cisplatin. However, its $\mathrm{IC}_{50}$ values show that the cytotoxic activity of the compound is significantly lower than the azpy derivatives [85]. Only a few trans-chloridoruthenium(II) compounds have been reported in the literature, and therefore this makes it necessary for more $\mathrm{Ru}(\mathrm{II})$ compounds with similar ligand architecture to be studied in order to find possible structure-activity relationships.

Ruthenium complexes with pyridyl-based ligands are of special interest due to a combination of easily constructed rigid chiral structures and useful photophysical properties. The large, rigid, and multidentate polypyridyl ligands confer shape and chirality to the ruthenium complexes that could be utilized to achieve customized DNA binding properties [88-90]. Following the literature reports on the pharmacological benefits of attaching carboxylic acid $(\mathrm{COOH})$ group in coordination complexes [91], ruthenium(II) complexes $\left[\mathrm{RuHCl}(\mathrm{bpy})\left(\mathrm{EPh}_{3}\right)(\mathrm{CO})\right]$ (bpy $=2,2^{\prime}$-bipyridine) 
<smiles></smiles>

FIGURE 19: $\mathrm{Ru}(\mathrm{II})$ compound trans-[RuII(Hpyrimol) $\left.{ }_{2} \mathrm{Cl}_{2}\right]$.

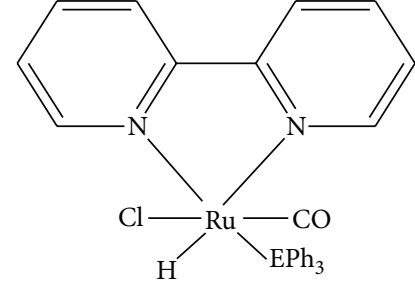

(28)

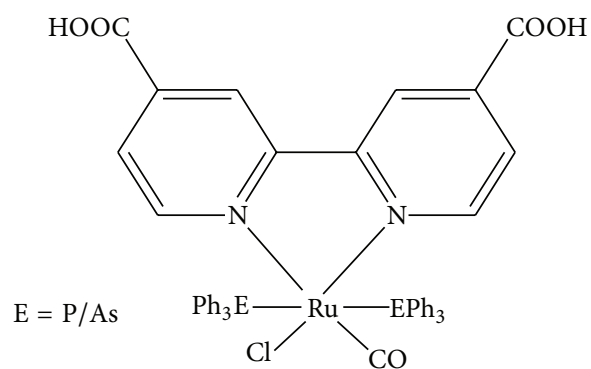

(29)

FIGURE 20: Ruthenium(II) bipyridyl complexes.

and $\left[\mathrm{RuCl}(\mathrm{HL})\left(\mathrm{EPh}_{3}\right)_{2}(\mathrm{CO})\right]$ ( $\mathrm{HL}=2,2^{\prime}$-bipyridine- $4,4^{\prime}$ dicarboxylic acid, $\mathrm{E}=\mathrm{P}$ or As) (28 and 29) have been prepared and explored for their interaction with DNA (Figure 20) [92]. An appropriate attachment of carboxylic acid could modulate the solubility of the complex, cell transport, and biological activity [91]. The interactions of these complexes with DNA revealed that the complexes could bind to CT-DNA through nonintercalation. The in vitro cytotoxic and antioxidant activities of the complexes against a panel of cancer cell lines and free radicals showed that carboxylic acid bearing compounds possess quite high anticancer and antioxidant activities and an apparent dependence of biological activities on incorporation of $\mathrm{COOH}$ in bipyridine moiety was noticed [91]. Furthermore, complexes containing bipyridine showed better binding affinity compared to those containing bipyridine dicarboxylic acids, and this could be attributed to the substitution of carboxyl acid groups in bipyridine, leading to differences in space configuration and the electron density distribution affecting the effective binding to DNA. The presence of ancillary ligands may also have an effect on the binding property since all octahedral complexes bind to DNA in three dimensions as reflected in better binding affinity for compounds which contained only one $\mathrm{PPh}_{3}$ or $\mathrm{AsPh}_{3}$ compared to those which contain two $\mathrm{PPh}_{3}$ or $\mathrm{AsPh}_{3}$ [92].

Cytostatic and cytotoxic properties of ruthenium(II) compounds (RDCs) containing ruthenium(II) atom covalently linked to carbon and nitrogen atoms (30-32) have been described (Figure 21) $[93,94]$. The compounds induced a $G_{1}$ cell cycle arrest and DNA fragmentation in mouse RDM4 (lymphoma) cells, human TK6 (B lymphoblastoid) cells, and A172 (glioblastoma) cells as sufficiently as cisplatin. The signalling pathways underlying these effects were also studied and revealed an induction of p53 and p57 protein levels, but with different intensities and kinetics, thereby suggesting p53-dependent and p53-independent modes of action. The results generally demonstrate a structure-function relationship because improved cytotoxicity was realised in ruthenium(II) compounds having a phenanthroline ligand [94].

On the basis of this structure-relationship studies, Vidimar et al. substituted the two acetonitrile ligands of RDC11 by a second phenanthroline, naming the new molecule RDC34 (33a) (Figure 22) [95]. An equivalent of RDC34 with another counter-ion $\left(\mathrm{PF}_{6}{ }^{-}\right)$was also synthesized (RDC37) (33b) (Figure 22). The redox potential of RDC34 was modified by adding either a $\mathrm{NO}_{2}$ (electron withdrawing) or a $\mathrm{NH}_{2}$ unit 


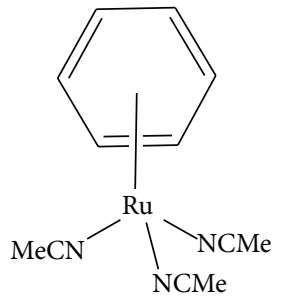

$2 \mathrm{BF}_{4}^{-}$

(30)

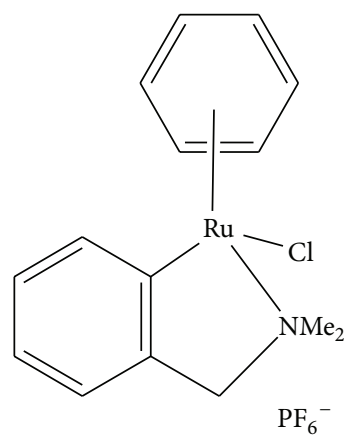

$(31)$

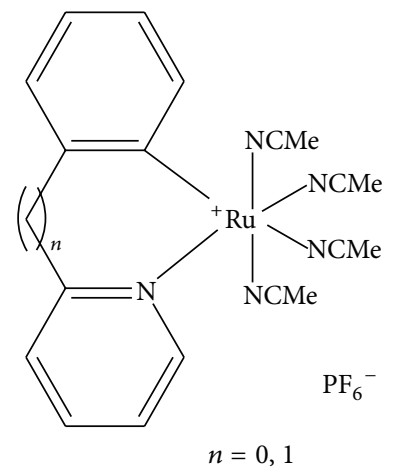

(32)

FIGURE 21: Ruthenium(II) complexes with carbon and nitrogen moieties.

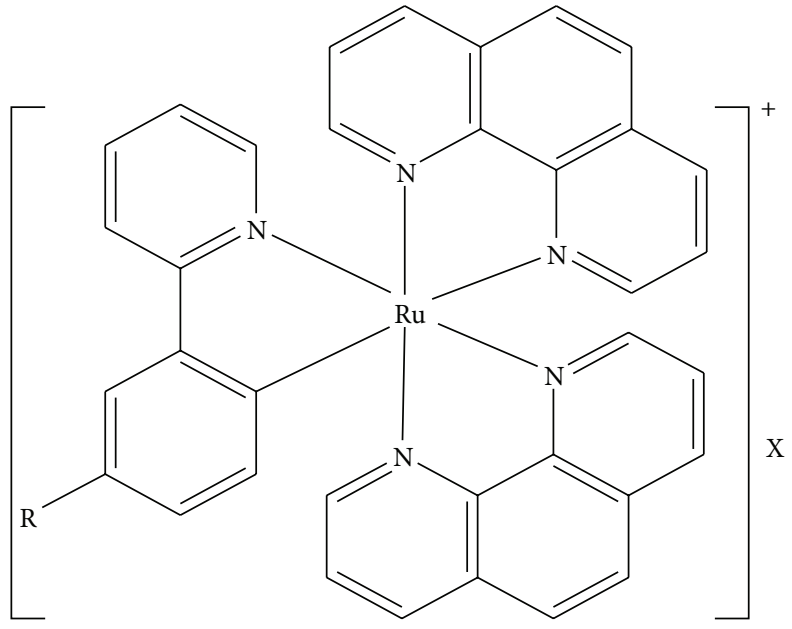

(33)
(a) $\mathrm{R}=\mathrm{H}, \mathrm{X}=\mathrm{CF}_{3} \mathrm{SO}_{3}{ }^{-}(\mathrm{RDC} 34)$
(b) $\mathrm{R}=\mathrm{H}, \mathrm{X}=\mathrm{PF}_{6}^{-}(\mathrm{RDC} 37)$
(c) $\mathrm{R}=\mathrm{NO}_{2}, \mathrm{X}=\mathrm{CF}_{3} \mathrm{SO}_{3}{ }^{-}(\mathrm{RDC} 40)$
(d) $\mathrm{R}=\mathrm{NH}_{2}, \mathrm{X}=\mathrm{CF}_{3} \mathrm{SO}_{3}{ }^{-}$(RDC 41)

FIGURE 22: Structures of RDC 34, RDC 37, RDC 40, and RDC 41.

(electron releasing) on the phenylpyridine ligand, leading to RDC40 (33c) and RDC41 (33d) (Figure 22), respectively [95]. The water-solubility of RDC34 was finally improved by adding a spermine unit to the phenylpyridine ligand, leading to RDC44 (34) (Figure 23) [96]. Cytotoxicity of the RDCs was first tested on human HCT116 (colon cancer) cells since colon cancers are one of the indications for platinum-derived treatments. Interestingly, compounds 33c containing the $\mathrm{NO}_{2}$ group showed an increased cytotoxicity $\left(\mathrm{IC}_{50}<2 \mu \mathrm{M}\right)$ compared to RDC11 and cisplatin. However, the addition of the $\mathrm{NH}_{2}$ group decreased the cytotoxic activity $\left(\mathrm{IC}_{50}=2-\right.$ $4 \mu \mathrm{M}, 33 \mathrm{~d})$ and that of the spermine moiety had an even worse effect, with the $\mathrm{IC}_{50}$ rising to over $16 \mu \mathrm{M}$ [95]. The work demonstrates that, by changing the ligands around the ruthenium, the ability of the compounds to interact with DNA is modified. Nevertheless, the complexes are more potent inducers of cancer cell death and they trigger the production of reactive oxygen species and the activation of caspase-8. The results also show that blocking reactive oxygen species production or caspase- 8 activities reduces the activity of the compounds significantly [95]. Altogether, the data suggest that water-soluble ruthenium(II)-derived compounds represent an interesting class of molecules that can target several proapoptotic signalling pathways leading to reactive oxygen species production and caspase- 8 activation [95].

A similar work is seen in ruthenium(II) methylimidazole complexes with the general formula $\left[\mathrm{Ru}(\mathrm{MeIm})_{4}(\mathrm{~N}-\mathrm{N})\right]^{2+}$ 


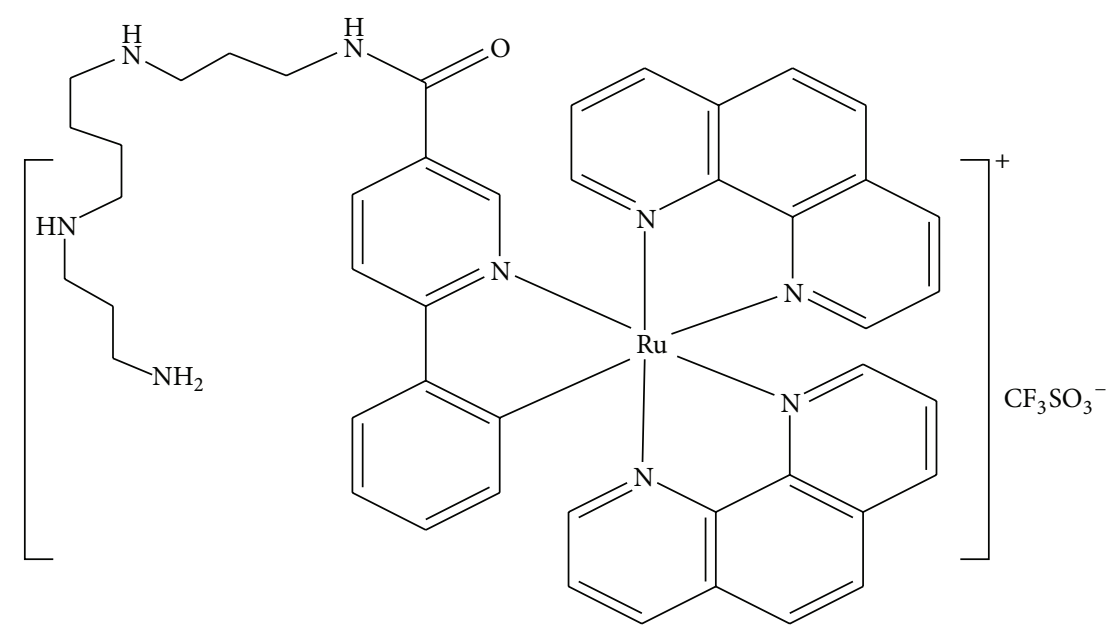

(34)

FIGURE 23: Structures of RDC 44.

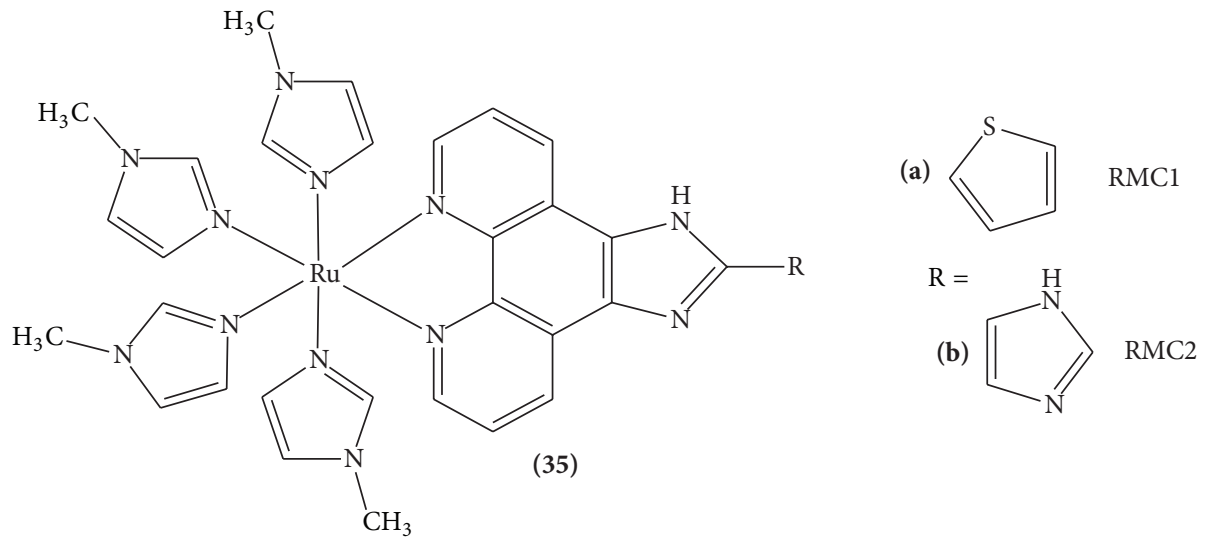<smiles></smiles>

(36)<smiles></smiles>

(37)

FIgURE 24: Ruthenium(II) methylimidazole complexes of general formula $\left[\mathrm{Ru}(\mathrm{MeIm})_{4}(\mathrm{~N}-\mathrm{N})\right]^{2+}$.

$(\mathrm{N}-\mathrm{N}=2$-(thiophene-2-yl)-1H-imidazo $[4,5-\mathrm{f}][1,10]$ phenanthroline (RMC1) (35a), 2-(1H-imidazol-4-yl)-1H-imidazo [4,5-f] [1,10]phenanthroline (RMC2) (29b), dipyrido $\left[3,2-\mathrm{a}: 2,3^{\prime}-\mathrm{c}\right]$ phenazine (RMC3) (36), and pyrazino $[2,3-\mathrm{f}]$ [1,10]phenanthroline) (RMC4) (37), MeIm = 1-methylimidazole (Figure 24) [97]. The methylimidazole based complexes have been prepared and studied with the hope that the combination of methylimidazole and N-N ligand 


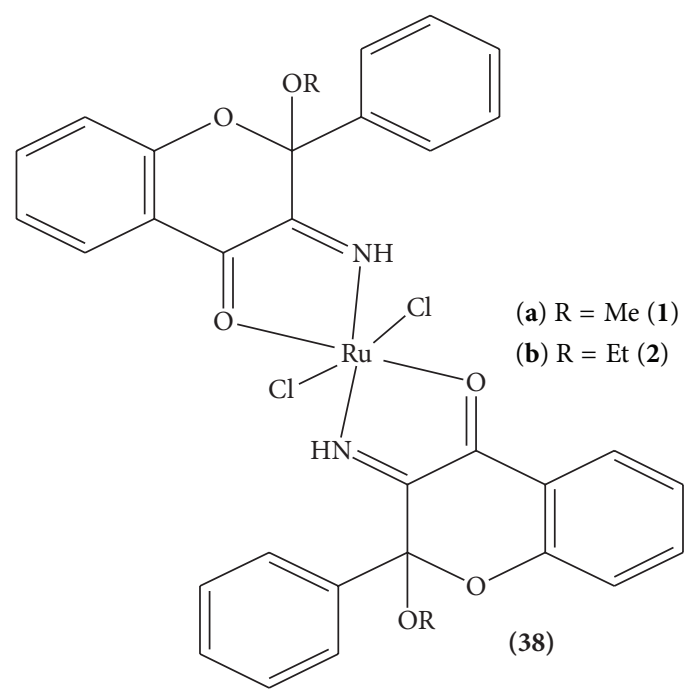

Figure 25: Structures of ruthenium(II) compounds: cis-dichloridobis(3-imino-2-methoxyflavanone)ruthenium(II) $3 \mathrm{H}_{2} \mathrm{O}$ (a) and cisdichloridobis(3-imino-2-ethoxyflavanone)ruthenium(II) $2 \mathrm{H}_{2} \mathrm{O}(\mathbf{b})$.

could enhance the antitumor activity and water-solubility. However, preliminary screening experiments showed that 36 and 37, containing methylimidazole ligand, possessed some biological activity [97]. In a successful attempt to improve water-solubility and of course antitumour activity, two new complexes 35a and 35b, bearing methylimidazole as the ancillary ligand and the main ligand incorporated with the thiophene and imidazole rings, were prepared. Methylimidazole is mostly used in drug design, as it is small molecule compounds with good water-solubility and a certain degree of biological activity $[98,99]$. The most active compound was $\mathbf{3 5 a}$, and it inhibited the growth of human A549 (lung adenocarcinoma) cells through induction of apoptotic cell death, as evidenced by the accumulation of cell population in sub-G1 phase. The compound also induced the depletion of mitochondrial membrane potential in A549 cells by regulating the expression of prosurvival and proapoptotic Bcl-2 family members. These results demonstrated that $35 \mathrm{a}$ induced cancer cell death by acting on both mitochondrial and death receptor apoptotic pathways [97].

The N-O moiety has been utilized in the preparation of active compounds cis-dichloridobis(3-imino-2-methoxyflavanone) ruthenium(II) $\cdot 3 \mathrm{H}_{2} \mathrm{O}(\mathbf{3 8 a})$ and cis-dichloridobis(3-imino-2-ethoxyflavanone) ruthenium(II) $\cdot 2 \mathrm{H}_{2} \mathrm{O}$ (38b) (Figure 25) [100]. The compounds are active towards human bladder carcinoma cell line (EJ) and its cisplatin resistant subline (EJcisR). The compounds were found to overcome the resistance to cisplatin of EJcisR cells and are less toxic to healthy human lymphocytes in vitro than cisplatin. The possible mechanism of CDDP-resistance of EJcisR cells of the two novel ruthenium compounds was investigated, and it was deduced that CDDP-resistance of EJcisR cells is based on partial loss of apoptotic pathway activating caspase- 8 and increased resistance to DNA strand breaks and/or alkali-labile sites. The compounds induced apoptosis so fast and this was attributed in part to the presence of large, lipophilic flavanone-based ligands that may facilitate their trans-membrane transport and redox activity [100].

An investigation of the interaction of ruthenium(II) complex, $\left[\mathrm{Ru}(\mathrm{dmp})_{2} \mathrm{PMIP}\right]^{2+}(\mathrm{dmp}=2,9$-dimethyl-1,10phenanthroline, PMIP = 2-(4-methylphenyl)imidazo[4,5f]1,10-phenanthroline) (39), a structural analogue of platinum(II) complex, with calf thymus DNA (CT-DNA), has been carried out on human A549 (lung cancer) cells in order to elucidate its binding mechanism and biological impact of the interactions (Figure 26) [12]. The steric hindrance exerted by the methyl group located on the ligands was expected to produce a moderate intercalative complex. Cell viability experiments indicated that the ruthenium complex showed significant dose-dependent cytotoxicity on human lung cancer cell line, and further experiments on the interaction with DNA indeed showed that the complex and CT-DNA formed a tight $1: 1$ complex with a binding constant exceeding $10^{6} \mathrm{M}^{-1}$ and with a binding mode of intercalation, suggesting that antitumour activity of the ruthenium(II) complex could be related to its interaction with DNA [12].

More interest has developed in ruthenium(II) polypyridyl complexes, and this is reflected in the preparation of ruthenium(II) $\beta$-carboline complex $\left[\mathrm{Ru}(\mathrm{tpy})(\mathrm{Nh})_{3}\right]^{2+}(\mathrm{tpy}=$ $2,2^{\prime}: 6^{\prime}, 2^{\prime \prime}$-terpyridine, $\mathrm{Nh}=$ Norharman) (40) (Figure 27) [101]. The compound was explored as a potentially antiproliferative agent. The $\beta$-carboline alkaloids are a class of synthetic and naturally occurring compounds that possess a large spectrum of pharmacological properties, which include sedative, anxiolytic, antiviral, antimicrobial, and antitumor activities [101]. Reports have revealed that some $\beta$-carboline alkaloids exert antitumor activities through multiple mechanisms, such as DNA binding and inhibiting topoisomerases I and II $[102,103]$. The $\left[\mathrm{Ru}(\mathrm{tpy})_{2}\right]^{2+}$ complexes are achiral, with the two tpy units perpendicular to each other, for which binding to DNA appears to be sterically possible. 


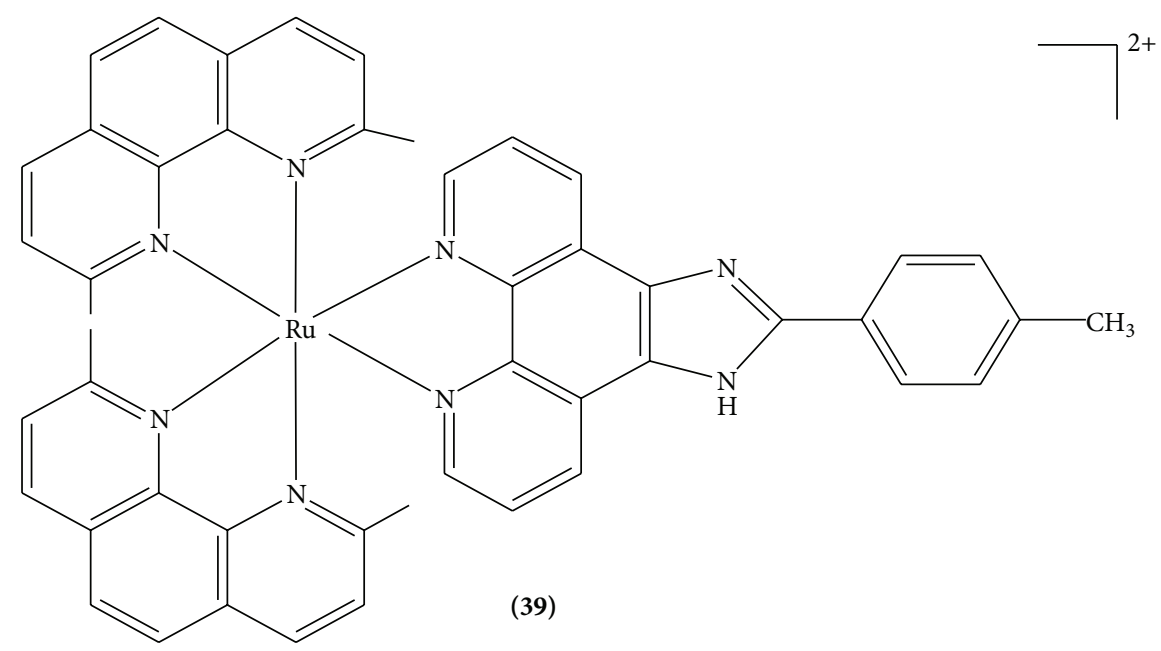

FIGURE 26: Ruthenium(II) polypyridyl complex.

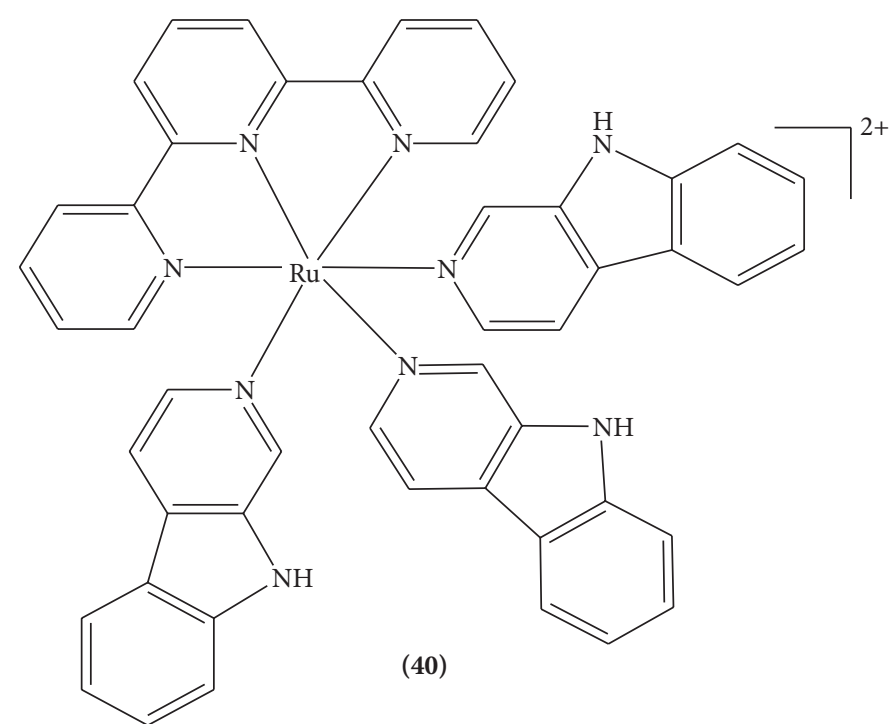

FIgURE 27: Ruthenium(II) $\beta$-carboline complex $\left[\mathrm{Ru}(\mathrm{tpy})(\mathrm{Nh})_{3}\right]^{2+}$.

The compound induced apoptosis against various cancer cell lines and had high selectivity between tumour cells and normal cells. In vivo examination indicated that the ruthenium(II) complex decreased mouse MCF-7 and HepG2 (hepatocellular carcinoma) tumour growth. Signalling pathways analysis demonstrated that this complex induced apoptosis via the mitochondrial pathway, as evidenced by the loss of mitochondrial membrane potential and the release of cytochrome $c$. When put together, these findings suggest that the compound exhibits high and selective cytotoxicity induced p53-mediated apoptosis [101].

\section{Conclusion}

After careful review of ruthenium(II) compounds, it becomes apparent that the compounds offer a promising approach to the development of new anticancer agents because they show remarkable features such as low general toxicity, the ability to mimic iron binding to biomolecules (transferrin, albumin), and stronger affinity for cancer tissues over normal tissues. Some of the compounds interact with DNA at the same initial sites (N7-guanine) as platinum compounds. However, the broad spectrum of anticancer activities displayed by the complexes makes it difficult to deduce their mechanism of action. Generally, cytotoxicity of the compounds is comparable or even better than that of cisplatin against a range of human cancer cells, thereby indicating that, for these types of ruthenium compounds, DNA is one of the targets of their action inside the cells. The use of chelating ligands with stronger binding to ruthenium appears to be desirable because these ligands offer advantages of structural stability in aqueous solution, thereby influencing in vitro anticancer activity of the complexes quite significantly. Furthermore, aqueous solubility of these ruthenium complexes gives rise to 
promising antitumor activities and high selectivity while also rendering them suitable for oral administration. However, instability and the difficult ligand exchange chemistry of inorganic ruthenium complexes present setbacks which can only be overcome with more stable organoruthenium complexes, in order to enhance their potential as drug candidates.

Half-sandwich organometallic ruthenium(II) arene complexes are emerging as promising candidates for cancer treatment. As seen in the review, the aromatic ligand attached to the complex occupies three coordination positions, thereby offering stability to the metal centre, while the remaining coordination sites can be occupied by the ligand that could impart antitumor activity together with ligands that can control electronic properties at the ruthenium centre. This architectural friendlies observed in half-sandwich arene ruthenium complexes offers an opportunity to improve their cytotoxic profile. The compounds possess excellent antitumor activities, with $\mathrm{IC}_{50}$ values much lower than those found for cisplatin. This could indicate that DNA is one of the targets of their action. Recent work on polymeric controlled drug delivery using polymer based ruthenium-cyclopentadienyl complexes could prove to be a promising alternative to the conventional drug delivery approaches in cancer therapy. All these findings suggest that further development of ruthenium compounds may contribute to the improvement of future chemotherapeutic protocols.

\section{Abbreviations}

AFM: Atomic force microscopy

CT: $\quad$ Calf thymus

DFT: Density functional theory

DMSO: Dimethyl sulfoxide

DNA: Deoxyribonucleic acid

NMR: Nuclear magnetic resonance

RDCs: Ruthenium(II) derived compounds

RMCs: Ruthenium(II) methylimidazole complexes

RNA: Ribonucleic acid.

\section{Conflict of Interests}

The authors declare that there is no conflict of interests regarding the publication of this paper.

\section{Acknowledgments}

The authors gratefully acknowledge the financial support from Govan Mbeki Research and Development Centre, University of Fort Hare, South Africa.

\section{References}

[1] B. Rosenberg, L. van Camp, and T. Krigas, "Inhibition of cell division in Escherichia coli by electrolysis products from a platinum electrode," Nature, vol. 205, no. 4972, pp. 698-699, 1965.

[2] B. Rosenberg, L. VanCamp, J. E. Trosko, and V. H. Mansour, "Platinum compounds: a new class of potent antitumour agents," Nature, vol. 222, pp. 385-386, 1969.
[3] A. Alama, B. Tasso, F. Novelli, and F. Sparatore, "Organometallic compounds in oncology: implications of novel organotins as antitumor agents," Drug Discovery Today, vol. 14, no. 9-10, pp. 500-508, 2009.

[4] T. V. Segapelo, I. A. Guzei, L. C. Spencer, W. E. V. Zyl, and J. Darkwa, "(Pyrazolylmethyl)pyridine platinum(II) and gold(III) complexes: synthesis, structures and evaluation as anticancer agents," Inorganica Chimica Acta, vol. 362, no. 9, pp. 3314-3324, 2009.

[5] T. W. Hambley, "The influence of structure on the activity and toxicity of Pt anti-cancer drugs," Coordination Chemistry Reviews, vol. 166, pp. 181-223, 1997.

[6] S. H. van Rijt and P. J. Sadler, "Current applications and future potential for bioinorganic chemistry in the development of anticancer drugs," Drug Discovery Today, vol. 14, no. 23-24, pp. 1089-1097, 2009.

[7] M. A. Jakupec, M. Galanski, V. B. Arion, C. G. Hartinger, and B. K. Keppler, "Antitumour metal compounds: more than theme and variations," Dalton Transactions, no. 2, pp. 183-194, 2008.

[8] I. Kostova, "Ruthenium complexes as anticancer agents," Current Medicinal Chemistry, vol. 13, no. 9, pp. 1085-1107, 2006.

[9] I. Ott and R. Gust, "Non platinum metal complexes as anticancer drugs," Archiv der Pharmazie, vol. 340, no. 3, pp. 117-126, 2007.

[10] D. Griffith, S. Cecco, E. Zangrando, A. Bergamo, G. Sava, and C. J. Marmion, "Ruthenium(III) dimethyl sulfoxide pyridinehydroxamic acid complexes as potential antimetastatic agents: synthesis, characterisation and in vitro pharmacological evaluation," Journal of Biological Inorganic Chemistry, vol. 13, no. 4, pp. 511-520, 2008.

[11] R. Margalit, H. B. Gray, M. J. Clarke, and L. Podbielski, "Chemical and biological properties of pentaamminerutheniumbleomycin complexes," Chemico-Biological Interactions, vol. 59, no. 3, pp. 231-245, 1986.

[12] P. Zhang, J. Chen, and Y. Liang, "DNA binding, cytotoxicity, and apoptotic-inducing activity of ruthenium(II) polypyridyl complex," Acta Biochimica et Biophysica Sinica, vol. 42, no. 7, pp. 440-449, 2010.

[13] J. Reedijk, "Metal-ligand exchange kinetics in platinum and ruthenium complexes," Platinum Metals Review, vol. 52, no. 1, pp. 2-11, 2008.

[14] L. Messori, A. Casini, D. Vullo, S. G. Haroutiunian, E. B. Dalian, and P. Orioli, "Effects of two representative antitumor ruthenium(III) complexes on thermal denaturation profiles of DNA," Inorganica Chimica Acta, vol. 303, no. 2, pp. 283-286, 2000.

[15] E. Gallori, C. Vettori, E. Alessio et al., "DNA as a possible target for antitumor ruthenium(III) complexes: a spectroscopic and molecular biology study of the interactions of two representative antineoplastic ruthenium(III) complexes with DNA," Archives of Biochemistry and Biophysics, vol. 376, no. 1, pp. 156$162,2000$.

[16] L. Messori, P. Orioli, D. Vullo, E. Alessio, and E. Iengo, "A spectroscopic study of the reaction of NAMI, a novel ruthenium(III) anti-neoplastic complex, with bovine serum albumin," European Journal of Biochemistry, vol. 267, no. 4, pp. 1206-1213, 2000.

[17] W. H. Ang and P. J. Dyson, "Classical and non-classical ruthenium-based anticancer drugs: towards targeted chemotherapy," European Journal of Inorganic Chemistry, vol. 2006, no. 20, pp. 4003-4018, 2006. 
[18] C. X. Zhang and S. J. Lippard, "New metal complexes as potential therapeutics," Current Opinion in Chemical Biology, vol. 7, no. 4, pp. 481-489, 2003.

[19] A. Bergamo and G. Sava, "Ruthenium complexes can target determinants of tumour malignancy," Dalton Transactions, no. 13, pp. 1267-1272, 2007.

[20] P. J. Dyson and G. Sava, "Metal-based antitumour drugs in the post genomic era," Dalton Transactions, no. 16, pp. 1929-1933, 2006.

[21] B. K. Keppler, H. Henn, U. M. Juhl, M. R. Berger, R. Niebel, and F. E. Wagner, "New ruthenium complexes for the treatment of cancer," in Ruthenium and Other Non-Platinum Metal Complexes in Cancer Chemotherapy, vol. 10 of Progress in Clinical Biochemistry and Medicine, pp. 41-69, Springer, Berlin, Germany, 1989.

[22] C. G. Hartinger, M. A. Jakupec, S. Zorbas-Seifried et al., "KP1019, a new redox-active anticancer agent-preclinical development and results of a clinical phase I study in tumor patients," Chemistry and Biodiversity, vol. 5, no. 10, pp. 21402155, 2008.

[23] P. Heffeter, K. Böck, B. Atil et al., "Intracellular protein binding patterns of the anticancer ruthenium drugs KP1019 and KP1339," Journal of Biological Inorganic Chemistry, vol. 15, no. 5, pp. 737-748, 2010.

[24] C. G. Hartinger, M. A. Jakupec, S. Zorbas-Seifried et al., "KP1019, a new redox-active anticancer agent-preclinical development and results of a clinical phase I study in tumor patients," Chemistry and Biodiversity, vol. 5, no. 10, pp. 21402155, 2008.

[25] R. Trondl, P. Heffeter, C. R. Kowol, M. A. Jakupec, W. Berger, and B. K. Keppler, "NKP-1339, the first ruthenium-based anticancer drug on the edge to clinical application," Chemical Science, vol. 5, no. 8, pp. 2925-2932, 2014.

[26] G. Sava, S. Zorzet, C. Turrin et al., "Dual action of NAMIA in inhibition of solid tumor metastasis: selective targeting of metastatic cells and binding to collagen," Clinical Cancer Research, vol. 9, no. 5, pp. 1898-1905, 2003.

[27] G. Sava, F. Frausin, M. Cocchietto et al., "Actin-dependent tumour cell adhesion after short-term exposure to the antimetastasis ruthenium complex NAMI-A," European Journal of Cancer, vol. 40, no. 9, pp. 1383-1396, 2004.

[28] D. Pluim, R. C. A. M. van Waardenburg, J. H. Beijnen, and J. H. M. Schellens, "Cytotoxicity of the organic ruthenium anticancer drug Nami-A is correlated with DNA binding in four different human tumor cell lines," Cancer Chemotherapy and Pharmacology, vol. 54, no. 1, pp. 71-78, 2004.

[29] F. Kratz, B. K. Keppler, M. Hartmann, L. Messori, and M. R. Berger, "Comparison of the antiproliferative activity of two antitumour ruthenium(III) complexes with their apotransferrin and transferrin-bound forms in a human colon cancer cell line," Metal-Based Drugs, vol. 3, no. 1, pp. 15-23, 1996.

[30] C. A. Smith, A. J. Sutherland-Smith, B. K. Keppler, F. Kratz, and E. N. Baker, "Binding of ruthenium(III) anti-tumor drugs to human lactoferrin probed by high resolution X-ray crystallographic structure analyses," Journal of Biological Inorganic Chemistry, vol. 1, pp. 424-431, 1996.

[31] A. R. Timerbaev, A. V. Rudnev, O. Semenova, C. G. Hartinger, and B. K. Keppler, "Comparative binding of antitumor indazolium [trans-tetrachlorobis( $1 H$ - indazole)ruthenate(III)] to serum transport proteins assayed by capillary zone electrophoresis," Analytical Biochemistry, vol. 341, no. 2, pp. 326333, 2005.
[32] B. Therrien, "Functionalised $\eta^{6}$-arene ruthenium complexes," Coordination Chemistry Reviews, vol. 253, no. 3-4, pp. 493-519, 2009.

[33] R. E. Aird, J. Cummings, A. A. Ritchie et al., "In vitro and in vivo activity and cross resistance profiles of novel ruthenium (II) organometallic arene complexes in human ovarian cancer," British Journal of Cancer, vol. 86, no. 10, pp. 1652-1657, 2002.

[34] G. S. Smith and B. Therrien, "Targeted and multifunctional arene ruthenium chemotherapeutics," Dalton Transactions, vol. 40, no. 41, pp. 10793-10800, 2011.

[35] M. J. Clarke, "Ruthenium metallopharmaceuticals," Coordination Chemistry Reviews, vol. 236, no. 1-2, pp. 209-233, 2003.

[36] Y. N. V. Gopal, D. Jayaraju, and A. K. Kondapi, "Inhibition of topoisomerase II catalytic activity by two ruthenium compounds: a ligand-dependent mode of action," Biochemistry, vol. 38, no. 14, pp. 4382-4388, 1999.

[37] C. Scolaro, A. Bergamo, L. Brescacin et al., "In vitro and in vivo evaluation of ruthenium(II)-arene PTA complexes," Journal of Medicinal Chemistry, vol. 48, no. 12, pp. 4161-4171, 2005.

[38] J. R. van Beijnum, A. Casini, A. A. Nazarov et al., "Organometallic ruthenium(II) arene compounds with antiangiogenic activity," Journal of Medicinal Chemistry, vol. 54, no. 11, pp. 38953902, 2011.

[39] I. Berger, M. Hanif, A. A. Nazarov et al., "In vitro anticancer activity and biologically relevant metabolization of organometallic ruthenium complexes with carbohydrate-based ligands," Chemistry, vol. 14, no. 29, pp. 9046-9057, 2008.

[40] E. E. Nifantyev, M. P. Koroteev, A. M. Koroteev et al., "Metal complexes based on monosaccharide bicyclophosphites as new available chiral coordination systems," Journal of Organometallic Chemistry, vol. 587, no. 1, pp. 18-27, 1999.

[41] M. Gras, B. Therrien, G. Süss-Fink, P. Š. Renfrew, A. K. Renfrew, and P. J. Dyson, "Water-soluble arene ruthenium complexes containing pyridinethiolato ligands: synthesis, molecular structure, redox properties and anticancer activity of the cations $\left[\left(\eta^{6} \text {-arene }\right) \mathrm{Ru}\left(\mathbf{p}-\mathrm{SC}_{5} \mathrm{H}_{4} \mathrm{NH}\right)_{3}\right]^{2+}, "$ Journal of Organometallic Chemistry, vol. 693, no. 21-22, pp. 3419-3424, 2008.

[42] K. Becker, C. Herold-Mende, J. J. Park, G. Lowe, and R. Heiner Schirmer, "Human thioredoxin reductase is efficiently inhibited by $\left(2,2^{\prime}: 6^{\prime}, 2^{\prime}\right.$-terpyridine)platinum(II) complexes. Possible implications for a novel antitumor strategy," Journal of Medicinal Chemistry, vol. 44, no. 17, pp. 2784-2792, 2001.

[43] C. A. Vock, W. H. Ang, C. Scolaro et al., "Development of ruthenium antitumor drugs that overcome multidrug resistance mechanisms," Journal of Medicinal Chemistry, vol. 50, no. 9, pp. 2166-2175, 2007.

[44] G. Süss-Fink, F.-A. Khan, L. Juillerat-Jeanneret, P. J. Dyson, and A. K. Renfrew, "Synthesis and anticancer activity of longchain isonicotinic ester ligand-containing arene ruthenium complexes and nanoparticles," Journal of Cluster Science, vol. 21, no. 3, pp. 313-324, 2010.

[45] F.-A. Khan, B. Therrien, G. Süss-Fink, O. Zava, and P. J. Dyson, "Arene ruthenium dichloro complexes containing isonicotinic ester ligands: synthesis, molecular structure and cytotoxicity," Journal of Organometallic Chemistry, vol. 730, pp. 49-56, 2013.

[46] G. V. Tsarichenko, V. I. Bobrov, and M. V. Smarkov, “Toxicity of isonicotinic acid," Pharmaceutical Chemistry Journal, vol. 11, no. 4, pp. 481-483, 1977.

[47] T. S. Morais, T. J. L. Silva, F. Marques et al., "Synthesis of organometallic ruthenium(II) complexes with strong activity against several human cancer cell lines," Journal of Inorganic Biochemistry, vol. 114, pp. 65-74, 2012. 
[48] V. Moreno, M. Font-Bardia, T. Calvet et al., "DNA interaction and cytotoxicity studies of new ruthenium(II) cyclopentadienyl derivative complexes containing heteroaromatic ligands," Journal of Inorganic Biochemistry, vol. 105, no. 2, pp. 241-249, 2011.

[49] M. H. Garcia, T. S. Morais, P. Florindo et al., "Inhibition of cancer cell growth by ruthenium(II) cyclopentadienyl derivative complexes with heteroaromatic ligands," Journal of Inorganic Biochemistry, vol. 103, no. 3, pp. 354-361, 2009.

[50] C. Scolaro, A. Bergamo, L. Brescacin et al., "In vitro and in vivo evaluation of ruthenium(II)-arene PTA complexes," Journal of Medicinal Chemistry, vol. 48, no. 12, pp. 4161-4171, 2005.

[51] B. Serli, E. Zangrando, T. Gianferrara et al., "Is the aromatic fragment of piano-stool ruthenium compounds an essential feature for anticancer activity? The development of new $\mathrm{Ru}^{I I}$ [9] $\mathrm{aneS}_{3}$ analogues," European Journal of Inorganic Chemistry, vol. 2005, no. 17, pp. 3423-3434, 2005.

[52] A. Valente, M. H. Garcia, F. Marques, Y. Miao, C. Rousseau, and P. Zinck, "First polymer 'ruthenium-cyclopentadienyl' complex as potential anticancer agent," Journal of Inorganic Biochemistry, vol. 127, pp. 79-81, 2013.

[53] H. Maeda, G. Y. Bharate, and J. Daruwalla, "Polymeric drugs for efficient tumor-targeted drug delivery based on EPR-effect," European Journal of Pharmaceutics and Biopharmaceutics, vol. 71, no. 3, pp. 409-419, 2009.

[54] P. Florindo, I. J. Marques, C. D. Nunes, and A. C. Fernandes, "Synthesis, characterization and cytotoxicity of cyclopentadienyl ruthenium(II) complexes containing carbohydratederived ligands," Journal of Organometallic Chemistry, vol. 760, pp. 240-247, 2014.

[55] D. S. Williams, G. E. Atilla, H. Bregman, A. Arzoumanian, P. S. Klein, and E. Meggers, "Switching on a signaling pathway with an organoruthenium complex," Angewandte ChemieInternational Edition, vol. 44, no. 13, pp. 1984-1987, 2005.

[56] E. Meggers, G. E. Atilla-Gokcumen, K. Gründler, C. Frias, and A. Prokop, "Inert ruthenium half-sandwich complexes with anticancer activity," Dalton Transactions, no. 48, pp. 1088210888, 2009.

[57] E. Meggers, G. E. Atilla-Gokcumen, H. Bregman et al., "Exploring chemical space with organometallics: ruthenium complexes as protein kinase inhibitors," Synlett, no. 8, pp. 1177-1189, 2007.

[58] J. É. Debreczeni, A. N. Bullock, G. E. Atilla et al., "Ruthenium half-sandwich complexes bound to protein kinase Pim-1," Angewandte Chemie International Edition, vol. 45, no. 10, pp. 1580-1585, 2006.

[59] D. S. Williams, G. E. Atilla, H. Bregman, A. Arzoumanian, P. S. Klein, and E. Meggers, "Switching on a signaling pathway with an organoruthenium complex," Angewandte ChemieInternational Edition, vol. 44, no. 13, pp. 1984-1987, 2005.

[60] H. Bregman and E. Meggers, "Ruthenium half-sandwich complexes as protein kinase inhibitors: an N-succinimidyl ester for rapid derivatizations of the cyclopentadienyl moiety," Organic Letters, vol. 8, no. 24, pp. 5465-5468, 2006.

[61] K. S. M. Smalley, R. Contractor, N. K. Haass et al., "An organometallic protein kinase inhibitor pharmacologically activates p53 and induces apoptosis in human melanoma cells," Cancer Research, vol. 67, no. 1, pp. 209-217, 2007.

[62] H.-K. Liu, S. J. Berners-Price, F. Y. Wang et al., "Diversity in guanine-selective DNA binding modes for an organometallic ruthenium arene complex," Angewandte Chemie International Edition, vol. 45, no. 48, pp. 8153-8156, 2006.

[63] R. L. Hayward, Q. C. Schornagel, R. Tente et al., "Investigation of the role of Bax, p21/Waf1 and p53 as determinants of cellular responses in HCT116 colorectal cancer cells exposed to the novel cytotoxic ruthenium(II) organometallic agent, RM175," Cancer Chemotherapy and Pharmacology, vol. 55, no. 6, pp. 577583, 2005.

[64] L. K. Filak, G. Mühlgassner, F. Bacher et al., "Rutheniumand osmium-arene complexes of 2-substituted indolo[3,2- c lquinolines: synthesis, structure, spectroscopic properties, and antiproliferative activity," Organometallics, vol. 30 , no. 2, pp. 273-283, 2011.

[65] L. K. Filak, S. Göschl, S. Hackl, M. A. Jakupec, and V. B. Arion, "Ruthenium- and osmium-arene complexes of 8-substituted indolo[3,2-c] quinolines: synthesis, $\mathrm{X}$-ray diffraction structures, spectroscopic properties, and antiproliferative activity," Inorganica Chimica Acta, vol. 393, pp. 252-260, 2012.

[66] M. F. Primik, S. Göschl, M. A. Jakupec, A. Roller, B. K. Keppler, and V. B. Arion, "Structure-activity relationships of highly cytotoxic copper(II) complexes with modified indolo[3,2-c ]quinoline ligands," Inorganic Chemistry, vol. 49, no. 23, pp. 11084-11095, 2010.

[67] K. Sharma, R. V. Singh, and N. Fahmi, "Palladium(II) and platinum(II) derivatives of benzothiazoline ligands: synthesis, characterization, antimicrobial and antispermatogenic activity," Spectrochimica Acta-Part A: Molecular and Biomolecular Spectroscopy, vol. 78, no. 1, pp. 80-87, 2011.

[68] A. C. G. Hotze, S. E. Caspers, D. de Vos et al., "Structuredependent in vitro cytotoxicity of the isomeric complexes $\left[\mathrm{Ru}(\mathrm{L})_{2} \mathrm{Cl}_{2}\right] \quad(\mathrm{L}=\mathrm{o}$-tolylazopyridine and 4-methyl-2phenylazopyridine) in comparison to $\left[\mathrm{Ru}(\text { azpy })_{2} \mathrm{Cl}_{2}\right]$," Journal of Biological Inorganic Chemistry, vol. 9, no. 3, pp. 354-364, 2004.

[69] R. E. Morris, R. E. Aird, P. del Socorro Murdoch et al., "Inhibition of cancer cell growth by ruthenium(II) arene complexes," Journal of Medicinal Chemistry, vol. 44, no. 22, pp. 3616-3621, 2001.

[70] S. W. Magennis, A. Habtemariam, O. Novakova et al., "Dual triggering of DNA binding and fluorescence via photoactivation of a dinuclear ruthenium(II) arene complex," Inorganic Chemistry, vol. 46, no. 12, pp. 5059-5068, 2007.

[71] C. Gaiddon, P. Jeannequin, P. Bischoff, M. Pfeffer, C. Sirlin, and J. P. Loeffler, "Ruthenium (II)-derived organometallic compounds induce cytostatic and cytotoxic effects on mammalian cancer cell lines through p53-dependent and p53-independent mechanisms," Journal of Pharmacology and Experimental Therapeutics, vol. 315, no. 3, pp. 1403-1411, 2005.

[72] Q. Wu, C. Fan, T. Chen et al., "Microwave-assisted synthesis of arene ruthenium(II) complexes that induce S-phase arrest in cancer cells by DNA damage-mediated p53 phosphorylation," European Journal of Medicinal Chemistry, vol. 63, pp. 57-63, 2013.

[73] W. Kandioller, C. G. Hartinger, A. A. Nazarov et al., “Tuning the anticancer activity of maltol-derived ruthenium complexes by derivatization of the 3-hydroxy-4-pyrone moiety," Journal of Organometallic Chemistry, vol. 694, no. 6, pp. 922-929, 2009.

[74] W. Kandioller, C. G. Hartinger, A. A. Nazarov et al., "From pyrone to thiopyrone ligands-rendering maltol-derived ruthenium(II)-arene complexes that are anticancer active in vitro," Organometallics, vol. 28, no. 15, pp. 4249-4251, 2009.

[75] M. P. Chelopo, S. A. Pawar, M. K. Sokhela, T. Govender, H. G. Kruger, and G. E. M. Maguire, "Anticancer activity of ruthenium(II) arene complexes bearing 1,2,3,4-tetrahydroisoquinoline amino alcohol ligands," European Journal of Medicinal Chemistry, vol. 66, pp. 407-414, 2013. 
[76] R. Fernández, M. Melchart, A. Habtemariam, S. Parsons, and P. J. Sadler, "Use of chelating ligands to tune the reactive site of half-sandwich ruthenium(II)-arene anticancer complexes," Chemistry, vol. 10, no. 20, pp. 5173-5179, 2004.

[77] A. S. Capilla, M. Romero, M. D. Pujol, D. H. Caignard, and P. Renard, "Synthesis of isoquinolines and tetrahydroisoquinolines as potential antitumour agents," Tetrahedron, vol. 57, no. 39, pp. 8297-8303, 2001.

[78] M. A. Letavic, J. M. Keith, J. A. Jablonowski et al., "Novel tetrahydroisoquinolines are histamine $\mathrm{H}_{3}$ antagonists and serotonin reuptake inhibitors," Bioorganic and Medicinal Chemistry Letters, vol. 17, no. 4, pp. 1047-1051, 2007.

[79] Y. Li, H. B. Zhang, W. L. Huang, X. Zhen, and Y. M. Li, "Synthesis and biological evaluation of tetrahydroisoquinoline derivatives as potential multidrug resistance reversal agents in cancer," Chinese Chemical Letters, vol. 19, no. 2, pp. 169-171, 2008.

[80] S. M. Meier, M. Hanif, Z. Adhireksan et al., "Novel metal(II) arene 2-pyridinecarbothioamides: a rationale to orally active organometallic anticancer agents," Chemical Science, vol. 4, no. 4, pp. 1837-1846, 2013.

[81] W. A. Kinney, N. E. Lee, R. M. Blank et al., "N-Phenyl-2-pyridinecarbothioamides as gastric mucosal protectants," Journal of Medicinal Chemistry, vol. 33, no. 1, pp. 327-336, 1990.

[82] A. H. Velders, H. Kooijman, A. L. Spek, J. G. Haasnoot, D. de Vos, and J. Reedijk, "Strong differences in the in vitro cytotoxicity of three isomeric dichlorobis(2-phenylazopyridine)ruthenium(II) complexes," Inorganic Chemistry, vol. 39, no. 14, pp. 2966-2967, 2000.

[83] A. H. Velders, K. van der Schilden, A. C. G. Hotze, J. Reedijk, H. Kooijman, and A. L. Spek, "Dichlorobis(2-phenylazopyridine)ruthenium(II) complexes: characterisation, spectroscopic and structural properties of four isomers," Dalton Transactions, no. 3, pp. 448-455, 2004.

[84] J. C. Chen, J. Li, L. Qian, and K. C. Zheng, "Electronic structures and SARs of the isomeric complexes $\alpha-, \beta-, \gamma$ $\left[\mathrm{Ru}(\text { mazpy })_{2} \mathrm{Cl}_{2}\right]$ with different antitumor activities," Journal of Molecular Structure: THEOCHEM, vol. 728, no. 1-3, pp. 93-101, 2005.

[85] S. Roy, P. U. Maheswari, A. Golobic, B. Kozlevc, and J. Reedijk, "Synthesis, crystal structure and biological studies of the highly anticancer active compound trans-dichloridobis(4-methyl2-N-(2-pyridylmethylene)-aminophenol)ruthenium(II)," Inorganica Chimica Acta, vol. 393, pp. 239-245, 2012.

[86] L. M. Chen, J. Liu, J. C. Chen et al., "Experimental and theoretical studies on the DNA-binding and spectral properties of water-soluble complex $\left[\mathrm{Ru}(\mathrm{MeIm})_{4}(\mathrm{dpq})\right]^{2+}$," Journal of Molecular Structure, vol. 881, no. 1-3, pp. 156-166, 2008.

[87] L. M. Chen, J. Liu, J. C. Chen et al., "Synthesis, characterization, DNA-binding and spectral properties of complexes $\left[\mathrm{Ru}(\mathrm{L})_{4}(\mathrm{dppz})\right]^{2+}(\mathrm{L}=\mathrm{Im}$ and MeIm)," Journal of Inorganic Biochemistry, vol. 102, pp. 330-341, 2008.

[88] C. W. Jiang, H. Chao, X. L. Hong, H. Li, W. J. Mei, and L. N. Ji, "Enantiopreferential DNA-binding of a novel dinuclear complex $\left[(\mathrm{bpy})_{2} \mathrm{Ru}(\mathrm{bdptb}) \mathrm{Ru}(\mathrm{bpy})_{2}\right]^{4+}$, , Inorganic Chemistry Communications, vol. 6, no. 6, pp. 773-775, 2003.

[89] J. G. Liu, B. H. Ye, Q. L. Zhang et al., "Enantiomeric ruthenium(II) complexes binding to DNA: binding modes and enantioselectivity," Journal of Biological Inorganic Chemistry, vol. 5, pp. 119-128, 2000.

[90] H.-L. Huang, Z.-Z. Li, Z.-H. Liang, and Y.-J. Liu, "Cell cycle arrest, cytotoxicity, apoptosis, DNA-binding, photocleavage, and antioxidant activity of octahedral ruthenium(II) complexes," European Journal of Inorganic Chemistry, vol. 2011, no. 36, pp. 5538-5547, 2011.

[91] M. Galanski and B. K. Keppler, "Carboxylation of dihydroxoplatinum(IV) complexes via a new synthetic pathway," Inorganic Chemistry, vol. 35, no. 6, pp. 1709-1711, 1996.

[92] T. Sathiya Kamatchi, N. Chitrapriya, S. K. Kim, F. R. Fronczek, and K. Natarajan, "Influence of carboxylic acid functionalities in ruthenium (II) polypyridyl complexes on DNA binding, cytotoxicity and antioxidant activity: synthesis, structure and in vitro anticancer activity," European Journal of Medicinal Chemistry, vol. 59, pp. 253-264, 2013.

[93] S. Fernandez, M. Pfeffer, V. Ritleng, and C. Sirlin, "An effective route to cycloruthenated n-ligands under mild conditions," Organometallics, vol. 18, no. 12, pp. 2390-2394, 1999.

[94] C. Gaiddon, P. Jeannequin, P. Bischoff, M. Pfeffer, C. Sirlin, and J. P. Loeffler, "Ruthenium (II)-derived organometallic compounds induce cytostatic and cytotoxic effects on mammalian cancer cell lines through p53-dependent and p53-independent mechanisms," The Journal of Pharmacology and Experimental Therapeutics, vol. 315, no. 3, pp. 1403-1411, 2005.

[95] V. Vidimar, X. Meng, M. Klajner et al., "Induction of caspase 8 and reactive oxygen species by ruthenium-derived anticancer compounds with improved water solubility and cytotoxicity," Biochemical Pharmacology, vol. 84, no. 11, pp. 1428-1436, 2012.

[96] L. Fetzer, B. Boff, M. Ali et al., "Library of second-generation cycloruthenated compounds and evaluation of their biological properties as potential anticancer drugs: passing the nanomolar barrier," Dalton Transactions, vol. 40, no. 35, pp. 8869-8878, 2011.

[97] X. Yang, L. Chen, Y. Liu et al., "Ruthenium methylimidazole complexes induced apoptosis in lung cancer A549 cells through intrinsic mitochondrial pathway," Biochimie, vol. 94, no. 2, pp. 345-353, 2012.

[98] F. J. Huo, C. X. Yin, and P. Yang, “The crystal structure, selfassembly, DNA-binding and cleavage studies of the [2]pseudorotaxane composed of cucurbit[6] uril," Bioorganic \& Medicinal Chemistry Letters, vol. 17, no. 4, pp. 932-936, 2007.

[99] R. S. Myers, R. E. Amaro, Z. A. Luthey-Schulten, and V. J. Davisson, "Reaction coupling through interdomain contacts in imidazole glycerol phosphate synthase," Biochemistry, vol. 44, no. 36, pp. 11974-11985, 2005.

[100] M. M. Kasprzak, L. Szmigiero, E. Zyner, and J. Ochocki, "Proapoptotic activity in vitro of two novel ruthenium(II) complexes with flavanone-based ligands that overcome cisplatin resistance in human bladder carcinoma cells," Journal of Inorganic Biochemistry, vol. 105, no. 4, pp. 518-524, 2011.

[101] Y. Chen, M.-Y. Qin, L. Wang, H. Chao, L.-N. Ji, and A.-L. Xu, "A ruthenium(II) $\beta$-carboline complex induced p53-mediated apoptosis in cancer cells," Biochimie, vol. 95, no. 11, pp. 20502059, 2013.

[102] S. L. Xiao, W. Lin, C. Wang, and M. Yang, "Synthesis and biological evaluation of DNA targeting flexible side-chain substituted $\beta$-carboline derivatives," Bioorganic and Medicinal Chemistry Letters, vol. 11, no. 4, pp. 437-441, 2001.

[103] Y. Li, F. S. Liang, W. Jiang et al., "DH334, a $\beta$-carboline anticancer drug, inhibits the CDK activity of budding yeast," Cancer Biology \& Therapy, vol. 6, pp. 1193-1199, 2007. 

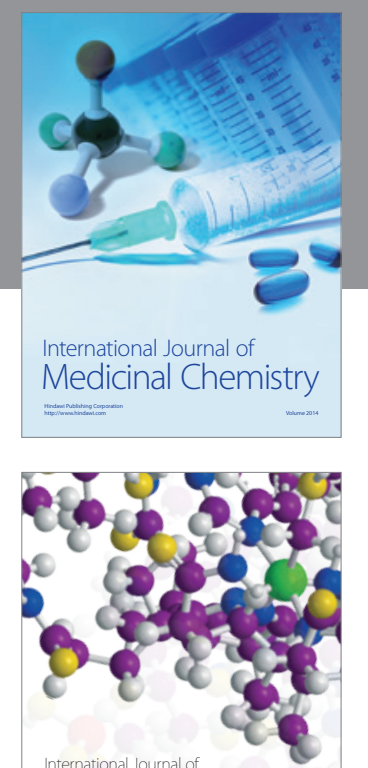

\section{Carbohydrate} Chemistry

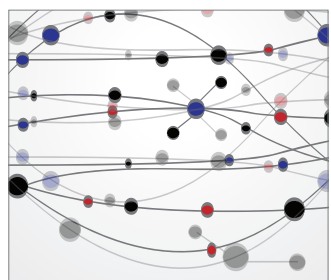

The Scientific World Journal
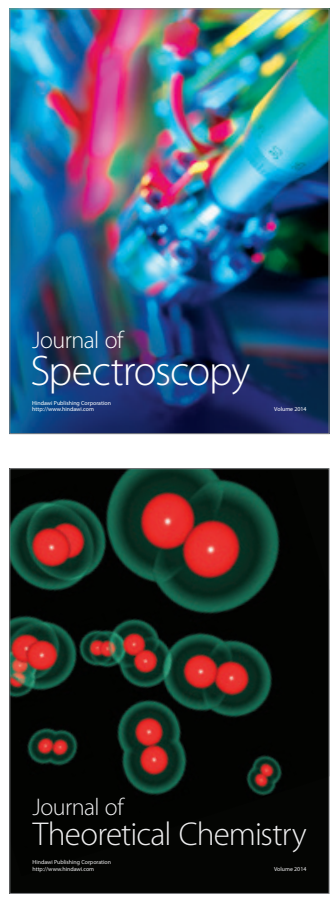
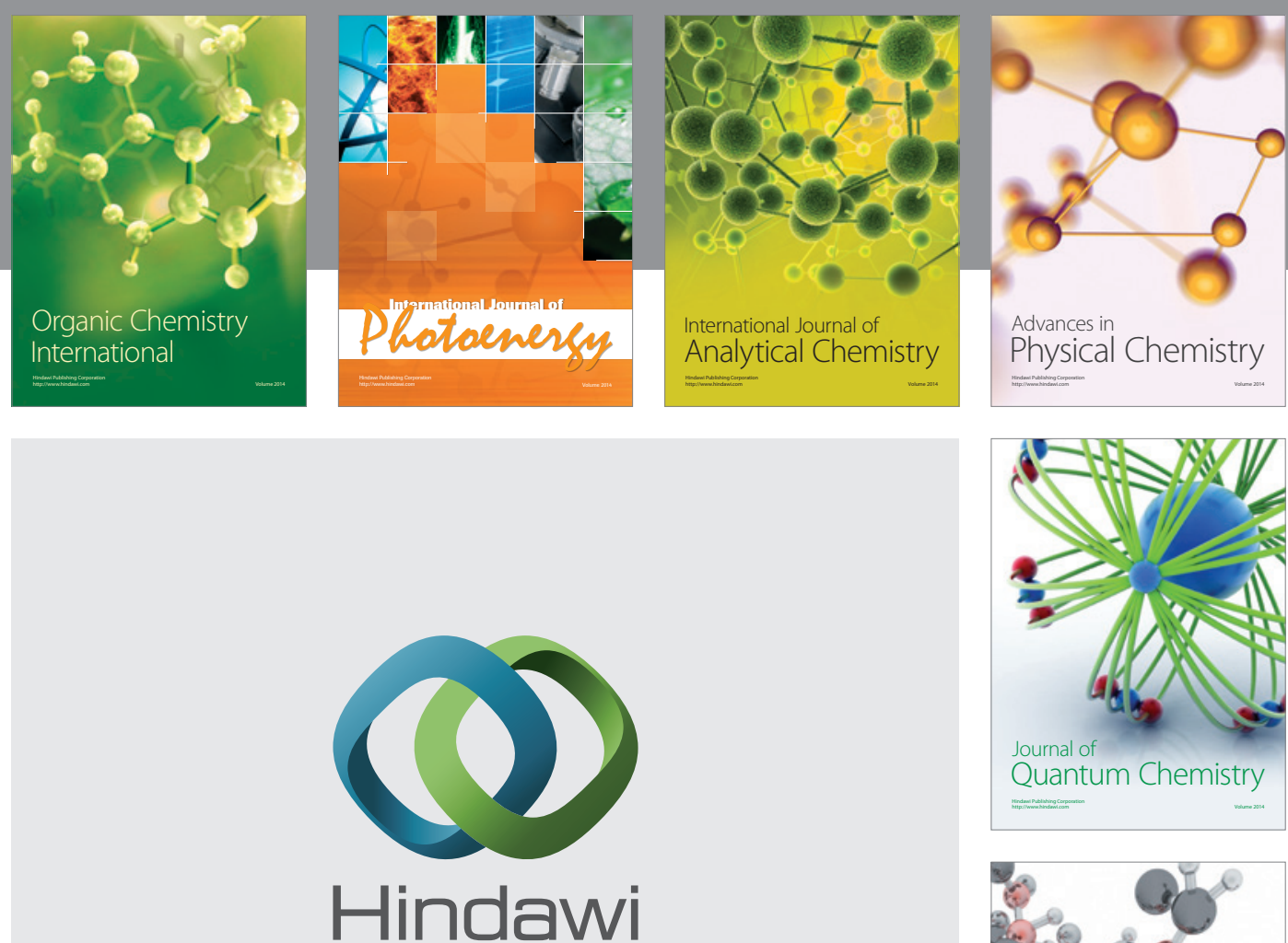

Submit your manuscripts at

http://www.hindawi.com

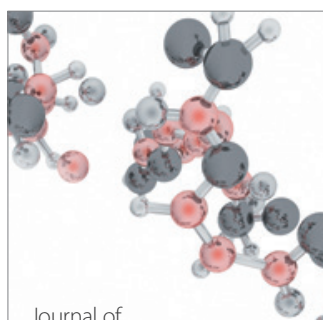

Analytical Methods

in Chemistry

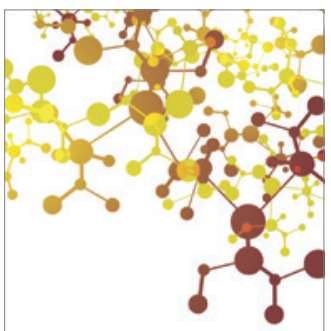

Journal of

Applied Chemistry

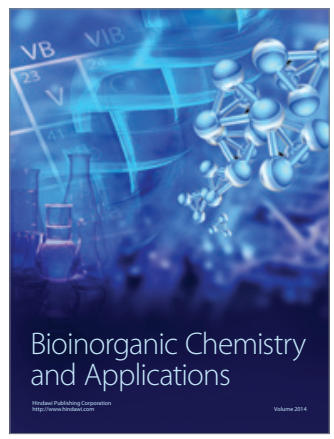

Inorganic Chemistry
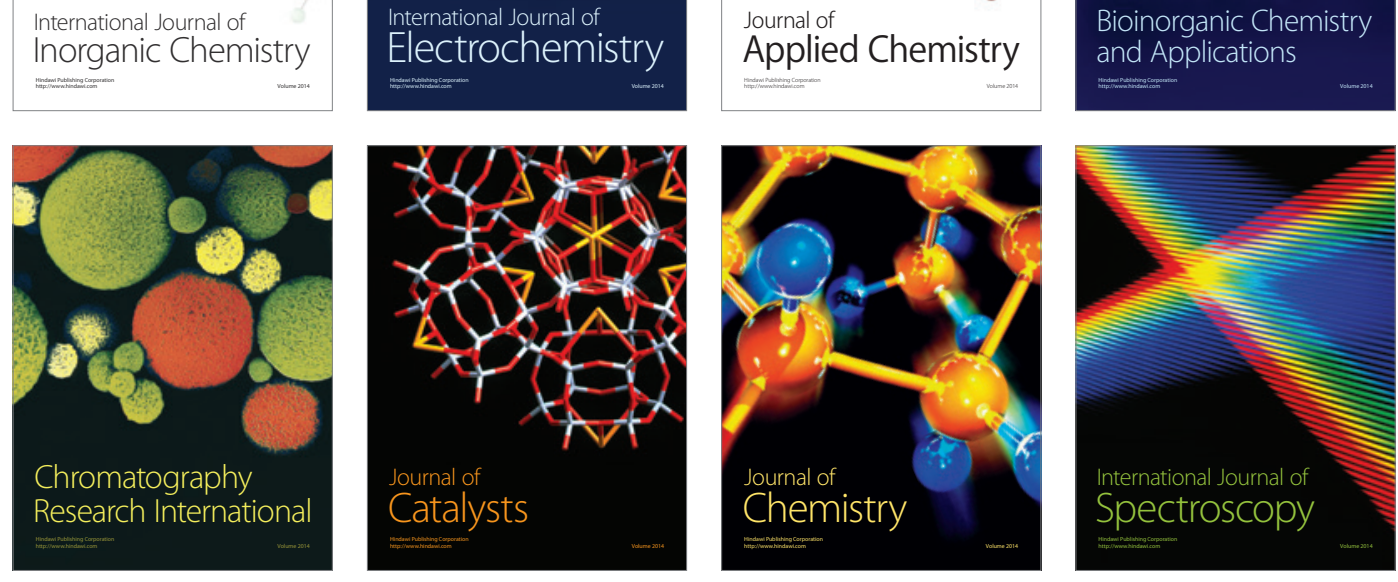